\title{
Identity and Schooling: Some Lessons for the Economics of Education
}

\author{
George A. Akerlof and Rachel E. Kranton ${ }^{1}$
}

\section{Introduction}

$\mathrm{T}$ HIS REVIEW culls noneconomic literature on education-by sociologists, anthropologists, reformers, and practitionersto present a new economic theory of students and schools. This theory integrates a sociological view of education with economic analysis. In a classic economic model, students choose effort (or time) in school to balance its discounted return with its opportunity cost, and resources determine school quality. $^{2}$ Economists now often append social interactions to this model but rarely examine the nature of these interactions. By reviewing literature outside of economics, we develop a theory where a student's primary motivation is his or her identity and the

\footnotetext{
${ }^{1}$ Akerlof: University of California, Berkeley; Kranton: University of Maryland. We thank Cyd Fremmer, Nisha Malhotra, and Eric Verhoogen for invaluable research assistance, Robert Akerlof, Paul Beaudry, Pierre Fortin, Abdeslam Maghraoui, Craig Riddell, and Janet Yellen for help and comments, and John McMillan and three anonymous referees for their critical review which helped us greatly improve the paper. Akerlof is grateful to the Canadian Institute for Advanced Research, the MacArthur Foundation, and the Brookings Institution for financial support. Kranton thanks the Institute for Advanced Study, where she spent 2001-2002 as a Deutsche Bank Member of the School of Social Science, for its hospitality and financial support.

2 We review the economic literature below.
}

quality of a school depends on how students fit in a school's social setting. ${ }^{3}$ This theory outlines fresh directions for research in the economics of education.

With the focus on identity and schools, this review gives a new perspective on the allocation of resources in education. We often see vast differences in educational outcomes with little difference in quantity of resources. These differences remain a puzzle to economists; as one of our referees argued, "economists do not have good models for explaining why school resources do or do not (as often found) affect the returns to schooling." The framework we develop might fill this gap. We translate key sociological concepts into an economic model of students and schools. At the forefront are a school's social setting and students' backgrounds. We show how sociological variables may affect educational outcomes, and how resources may change the returns to different policies.

The literature we review represents a major (in our view, the predominant) line in the sociology of education. The concepts we adopt-ideal type, identity, and social category - are as basic to sociology as supply and

${ }^{3}$ Thus we follow Judith Harris (1998), who writes "children want to be successful children," and James Coleman (1961), who argues adolescents want to fit in. 
demand to economics. In schools of education, the syllabi of core courses are filled with works that apply these concepts to schooling. ${ }^{4}$ Of course, there is now much sociology that is indistinguishable from economics. Economics, however, has not adopted core sociological concepts. This omission may be for good reason: we have heard many economists say these concepts are too fuzzy to inform either theory or empirical work. Nonetheless, it might be worthwhile to consider how central sociological concepts may explain outcomes that cannot be explained by a standard economic model. Without a model that mirrors this sociology, economic analysis produces only partial answers to key questions. For example, what is the impact of resources on academic attainment? What are the important elements of school reform? Economists can answer whether additional resources enhance schooling, but not when these resources will be effective, or why. The models below give tentative answers and directions for empirical investigation. The effectiveness of resources will depend upon interaction between the resources used and student formation of academic identity.

Our interpretation of the noneconomic literature relies on previous work, Akerlof and Kranton (2000), which advances a notion of utility where an individual's identity, or sense of self, is salient. An individual gains utility when her actions and those of others enhance her self-image. Furthermore, selfimage, or identity, is associated with the social environment: People think of themselves and others in terms of different social categories. Examples of social categories include racial and ethnic designations, and in the school context include, for example, "jock" and "nerd." Prescriptions give the ideal, or stereotypical physical attributes and

\footnotetext{
${ }^{4}$ See, for example, Harvard University's Professor Sara Lawrence-Lightfoot's syllabus on the sociology of education: http://icommons.harvard.edu/ gse-a107/syllabus/Syllabus.html.
}

behavior, of people in each category. Individuals then gain or lose utility insofar as they belong to social categories with high or low social status and their attributes and behavior match the ideal of their category. We use this basic model of utility to understand student behavior in schools.

In this introduction we first describe our readings in the noneconomic education literature and our interpretation of it. We then discuss what may be missing from the economic literature and why the inclusion of these sociological variables could make a difference to economic analysis.

\subsection{Outline and Interpretation of Noneconomic Literature}

We begin with James Coleman's (1961) study of ten Illinois high schools in the late 1950 s, Adolescent Society. Coleman pioneered the research on students' social arrangements. From student questionnaires, Coleman found that students literally divide themselves into social categories - categories that should be familiar to anyone who has attended a United States high school: "nerds," "jocks," "leading crowd," "burnouts," and such. Associated with each category is an ideal in terms of physical attributes and behavior. Coleman found that these categories influenced academic performance. Following Adolescent Society, numerous scholars, especially Penelope Eckert (1989), Richard Everhart (1983), and Douglas Foley (1990), have described student motivation and social division in fine ethnographic detail. ${ }^{5}$

We depict this work in a model where students maximize utility by making two choices. They choose their social category, and they choose effort in school. ${ }^{6}$ When choosing categories, students try to fit in: They consider the match between their own

\footnotetext{
${ }^{5}$ For antecedents, see August Hollingshead (1949).

6 We use the word "choice" advisedly. As in classic utility theory, we do not presume that individuals are conscious of the reasons for their choices. See Akerlof and Kranton (2000) for discussion.
} 
characteristics and the ideal characteristics of jocks, burnouts, and nerds. When choosing effort, students also try to fit in. They consider the match between their own actions and the ideal behavior of their chosen categories. Ethnographies of high schools reveal that social divisions and students' identities can be a dominant influence on achievement.

We then consider the view-held by historians, contemporary sociologists, anthropologists, and educators--of schools as institutions, with social goals. ${ }^{7}$ In this view, schools not only impart skills. Schools also impart an image of ideal students, in terms of characteristics and behavior. ${ }^{8}$ School rituals-pep rallies, home-room announcements, assemblies-and day-to-day interactions in classrooms, hallways, and gymnasiums reveal the nature of this ideal. Teachers, administrators, and coaches praise and reward some students, while they disapprove of and punish others. These features and occasions define what we call a school's social category and its ideal student. Students with backgrounds similar to this category readily identify with the school. Others, however, do not fit in so easily. Sociologists consider these interactions important, but economic research has yet to examine this setting.

We first consider assimilation in American schools of the early twentieth century, as described by historians. In the model, schools promote a single social category, and students have two choices. They choose whether or not to adopt the school's social category, and they choose their effort. The historians see these choices as particularly poignant for students whose backgrounds

\footnotetext{
${ }^{7}$ Thus Allan Bloom (1987, p. 26) writes that "Every educational system . . . wants to produce certain types of human beings."

${ }_{8}^{8}$ Anthony Bryk, Valerie Lee, and Peter Holland (1993, pp. 146-47), for example, describe the Statement of Philosophy of St. Ignatius School, which we discuss below. Allen Peshkin (1985) provides the description of the ideal student at a fundamentalist Christian school.
}

conflict with the school's ideal. The students are likely to resent the implication, inherent in their schooling, that there is something wrong with their backgrounds, and by extension, that there is something wrong with themselves. To avoid a loss in self-image, a student rejects the school and consequently exerts low levels of effort. ${ }^{9}$ Studies as recently as the 1990's reveal similar problems among today's African-American students, Hispanic students, and other minorities. ${ }^{10}$

We use the same model to capture educators' views of contemporary United States public schools. This view, best exposited by Arthur Powell, Eleanor Farrar, and David Cohen (1985), is that the typical U.S. high school today is "Shopping Mall High." In the language of our framework, such schools fail to promote a particular social category. ${ }^{11}$ Instead, principals and teachers preach tolerance, and students are allowed wide choice in classes and curricula. Educators say that such laxity produces academic mediocrity. In our interpretation, school administrators face a trade-off between promoting a single ideal or offering students a choice. With choice, more students in a diverse population find ways to identify with the school. The outcome is more "democratic" in that more students are engaged in the school, but some students acquire lower skills.

\footnotetext{
${ }^{9}$ Pediatricians Andrea Bonny et al. (2000) found that "school connectedness," the extent to which students identify with their schools, is an indicator of safer behaviors and better health outcomes. School connectedness was a better predictor than "family connectedness." In this paper, we explore the various aspects of schooling that can affect school connectedness and thereby academic achievement.

${ }^{10} \mathrm{~A}$ recent article in the Harvard Education Letter, for example, tells how researchers now consider the "connectedness" or relationship between students and their schools as central to the gap in test scores between whites and other students (Michael Sadowski 2001).

${ }^{11}$ Powell, Farrar, and Cohen (1985) describe the typical U.S. public high school as Shopping Mall High because of the great deal of choice given to students and the failure of the schools to impose educational values.
} 
We then consider school reform programs and the difference between public and private schools. Educators argue that legal innovations and changes in social attitudes in the 1960s and 1970s have made it difficult for public schools to promote standards for students' behavior. ${ }^{12}$ In contrast, private school administrators and teachers spend considerable resources to delineate prescriptions for student behavior and ensure that students identify with the school and its ideals. Successful experiments in public school reform, such as the Central Park East Elementary and Secondary Schools in Harlem and the Comer Schools in New Haven, have similar strategies. We see these schools, in our economic terminology, as investing in students' self-images and relationships with the school. The schools reduce the initial social differences among the students and create a community, with an ideal of academic excellence. ${ }^{13}$

\subsection{The Economics of Education: A Brief Summary and Two Missing Pieces}

Here we review the economic literature, with special attention to the influence of sociology on economic research and an

\footnotetext{
12 We discuss the legal innovations below. For discussion of the social climate, see Gerald Grant (1988).

${ }^{13}$ In their textbook for educators, Edward Wynne and Kevin Ryan (1997) emphasize the role of community in a school. They claim that "proper student conduct is enhanced by a code of conduct that not only prohibits wrongdoing, but also encourages students to do things that immediately help others." Their checklist for school principals of methods to promote character shows concretely some of the ways in which schools can enhance a sense of community. These include such items as academic team competitions in or among schools (e.g., math or spelling bees), band or choir, cheerleading, classroom or building clean-up, class monitors, messengers, hall guards, and office assistants, crossing guards and patrol duty, community service, dramatic presentations, fund-raising, clubs, sports, school newspaper, peer tutoring, well-organized academic group projects, library aides, athletic or sportsmanship awards, certificates, mention in school newspaper, mention in newsletter to parents, mention over public address system, mention on report card, note home to parents, pep rally, posting name or photo, gold star or sticker, and special jackets or garments (pp. xxiii-xxiv).
}

assessment of what is still missing from economic analysis.

Since Theodore Schultz (1960) and Gary Becker (1964) introduced the concept of human capital, economists have been concerned with resources devoted to education and the return to education. A large body of empirical work has examined the impact of resources on education outcomes. Prominent recent examples include David Card and Alan Krueger (1992a,b), Julian Betts (1995), Ronald Ferguson (1998b), Eric Hanushek (1996), Caroline Hoxby (2000), Krueger and Diane Whitmore (1999). These studies have variously viewed resources in terms of school expenditures, teacher-student ratios, and teacher quality, and the returns to education in terms of earnings, as well as other intermediate measures such as enhanced test scores, continuation rates, and rates of college application. As we will discuss further in the conclusion, the sociological literature, in contrast, is remarkably silent on the return to resources devoted to education. The framework we develop suggests a synthesis of the sociological and economic viewpoints, providing insights into how resources can be effectively deployed.

The delivery of education services and market structure is a second classic question in the economics of education. In Free to Choose, Milton Friedman and Rose Friedman (1980) propose privatization and school vouchers as an antidote to the agency problems inherent in governmental monopoly schools. Economists have since considered both theoretically and empirically the implications of market structure on educational attainment. Empirical studies have measured the relative effectiveness of public and private schools (e.g. William Evans and Robert Schwab 1995) and asked whether competition increases school quality (e.g. Hoxby 1996). On the theoretical side, Charles Manski (1992) and Dennis Epple and Richard Romano (1998) build models of private and public schools and ask how voucher policies affect the set of students 
that attend each type of school. The latter paper considers peer group effects in educational attainment; private schools offer fellowships to high-quality students because they enhance the learning of other students. Of course, peer group effects are a prominent topic in sociology and are now a wellresearched area within economics. ${ }^{14}$ However, as we have already noted and will discuss extensively below, the sociological literature indicates that the difference between private and public schools goes beyond peer group effects and the selection (or self-selection) of students. Private schools pursue different social goals and have greater freedom to invest in the identity of their students.

Following Charles Tiebout (1956), school funding is a third topic that has occupied economic researchers. Roland Benabou (1993) and Raquel Fernandez and Richard Rogerson (1996), for example, offer theoretical studies of community formation and its impact on school funding. Recently, economists have considered a key sociological variable: ethnic homogeneity. Claudia Goldin and Lawrence Katz (1997) find that ethnically homogeneous communities led the "high-school movement" in the early twentieth-century United States. More homogeneous communities had higher school funding and greater high-school attendance. Alberto Alesina, Reza Baqir, and William Easterly (1999) show the continued positive impact of homogeneity on school funding in the United States, and Edward

\footnotetext{
${ }^{14} \mathrm{~A}$ body of work in economics considers schools and peer group effects on educational outcomes: e.g., Hanushek (1971), Anita Summers and Barbara Wolfe (1977), Evans, Wallace Oates and Schwab (1992), Alejandro Gaviria and Steven Rafael (1997), David Levine and Gary Painter (2000), and Bruce Sacerdote (2000). These authors and others attempt to disentangle the impact of peer behavior on achievement from other student and school characteristics, where the peer group is often defined at the school level. The modeling below emphasizes the social characteristics that lead students to choose different peer groups within a school, and how school policies affect this choice.
}

Miguel (1999) has shown that tribally diverse school districts in Kenya have lower levels of funding. ${ }^{15}$ The sociological literature we interpret gives a window on basic microeconomic effects of ethnicity on the supply and demand for education. The motivation of students themselves may derive from their ethnic background and the match between themselves and schools. Schools as institutions may themselves promote a particular social category and ideal student; they may also adjust their policies to accommodate an ethnically diverse student population.

Other papers in economics have considered less traditional questions in education, such as ideology imparted by schooling. Samuel Bowles and Herbert Gintis (1976) argue that the U.S. educational system was designed to produce compliant workers. Michael Kremer and Andrei Sarychev (2000) build a political economy model where schools inculcate their students with an ideology. In a democracy, the populace may vote for a public school system (and against school choice), in order to promote ideological homogeneity.

John Bishop's (1998) paper on students' social norms comes closest to the sociology and modeling we present below. His work, like ours, focuses on individual student motivation in the school's social context. He asks why social norms favor athletic over academic performance. He argues that academic success rewards only the individual, while athletic success rewards students in the school as a whole. Hence, students would cooperate in learning, rather than harass those who achieve, if academic rewards depended on outside testing and competition. The sociology we discuss below, and our modeling of it, paints a more microeconomic picture of student motivation, as derived from students' identities. We examine how social categories,

\footnotetext{
${ }^{15}$ Miguel also provides a theoretical model in which heterogeneity reduces school quality, and therefore lowers the return to funding.
} 
and the prescriptions for those categories, affect academic achievement, as well as how schools can influence students' choices.

While economists have begun to examine many substantive areas of the sociology of education, our reading of the literature indicates that two related themes have thus far eluded economic analysis. First is a sociological view of the student as the primary decision maker. Second is the conception of the school as a social institution. In sections 2 and 3 below, respectively, we elaborate on these themes. Each section has (i) a discussion of the noneconomic literature, (ii) a basic model that gives a guideline of how economic theory could and should capture the relevant sociology, and (iii) a discussion of existing evidence that supports the modeling. In section 4 we integrate these sociological themes into an economic analysis of resource allocation within schools. Section 5 considers black-white differences in education. Section 6 reviews the implications of the theory in this paper for empirical research, and section 7 concludes.

\section{Identity and Utility}

We begin by modeling the sociology of high-school life presented by Coleman and his followers. We posit a model of student preferences where self-image, or identity, is salient, based on the general model of utility in Akerlof and Kranton (2000). Much of the research in social psychology that is the basis for this model was conducted with school-age children as subjects, thus making it appropriate to adapt this model to the field of education. We describe our model along with a brief summary of this social psychology research.

\subsection{A Student Utility Function}

We construct a model of a student's utility where identity, or self-image, is salient. As in a standard model of education, a student's utility will depend on her effort in school and the pecuniary returns to this effort. Let $e_{i}$ be individual $i$ s effort in school, and let $k\left(e_{i}\right)$ be $i$ 's skills, or human capital. ${ }^{16}$ Typically, the pecuniary benefits of $e_{i}$ are the returns to skills in the labor market. Pecuniary costs include $i$ 's foregone leisure or cost of effort. ${ }^{17} \mathrm{~A}$ standard utility function would posit $i$ 's utility is a function of income and effort: $U_{i}=U_{i}\left(w \cdot k\left(e_{i}\right), e_{i}\right)$, where $w$ is the wage rate per unit of skill.

We now add identity to this utility function. As in Akerlof and Kranton (2000), we begin with a set of social categories $\mathbf{C}$. Again, these categories may include racial and ethnic designations, gender, and in the school context include, for example, "jocks" and "nerds." Prescriptions $\mathbf{P}$ give the ideal characteristics and behavior for each category. An individual $i$ is assigned to a category, and we denote this assignment $c_{i}{ }^{18} i$, self-image, $I_{i}$, depends on the match between her behavior and characteristics with the ideals for her category. Student $i$ 's utility is then $U_{i}=U_{i}\left(w k\left(e_{i}\right), e_{i}, I_{i}\right)$, where $I_{i}=I_{i}\left(e_{i}, c_{i} ; \mathbf{\varepsilon}_{i}, \mathbf{P}\right)$ and $\varepsilon_{i}$ are $i$ 's characteristics. We use the word identity to describe both a student's assigned category and the payoffs associated with self-image. Thus, we speak of gains or losses in identity, which are the gains or losses in utility derived from the term $I_{i}$.

This model describes behavior revealed by social psychology experiments. These experiments demonstrate how assigned social categories influence behavior. The classic Robbers Cave experiment is one illustration. In this experiment, two groups of randomly selected eleven-year-old boys were taken to a park in

\footnotetext{
${ }^{16}$ Our concept of "effort" summarizes the student's input into education. It is thus a composite of both the length of time spent in school and the student's effort while there.

${ }^{17}$ Other costs include foregone wages and direct expenditures on education such as books and tuition.

${ }^{18}$ In a more general framework, $i$ could also assign others to social categories.
} 
Oklahoma, where they were kept apart for a week. During this week, researchers found the boys developed a sense of belonging to their group. When they met for a tournament in the second week, the eleven-year-old equivalent of war broke out, complete with name-calling and stereotyping. ${ }^{19}$ Minimal group experiments show that competition is not necessary for category assignments to affect behavior. Experiments, with both children and adults, show that subjects are more likely to give rewards to those assigned the same label than to others, even when the assignment is random, recipients are anonymous, and there is no impact on own payoffs. ${ }^{20}$

Outside of experiments, the behavior of school-age children also reveals an appreciation of social categories. Children are aware of gender categories, and beyond the ages of five or six, self-segregate into groups of boys and girls. ${ }^{21}$ Even very young children may have some understanding of the social categories and prescriptions for "blacks" and "whites." Lisa Delpit (1995, p. 48) tells of the new black first-grader who asked her black teacher why she was speaking in a different voice, a voice blacks use when interacting with whites: "Teacher, how come you talkin' like a white person? You talkin' just like my momma talk when she get on the phone." 22

\footnotetext{
${ }^{19}$ For description and discussion of this experiment, see Roger Brown (1986).

${ }^{20}$ For description and discussion of minimal group experiments and children subjects, see Brown (1986) and Henri Tajfel and John Turner (1979, pp. 13-15).

${ }^{21}$ For an excellent survey of the research on group distinctions and social categories, see Margaret Wetherell (1996, pp. 219-27).

${ }_{22}$ Students also understand ethnic social categories, and may behave accordingly. In a recent survey of high school students in Miami and San Diego, Rubén Rumbaut (2000) finds that grade point average varied according to students' ethnic self-identification (Hispanic, Vietnamese, etc.) controlling for parents' socioeconomic status. He also found that the more students identified as being American, the lower was academic achievement.
}

\subsection{High School: Jocks, Nerds, and Burnouts}

We adapt the preceding model to capture the behavior of high-school students described in Coleman (1961) and later studies; e.g., Everhart (1983), Eckert (1989), Foley (1990). This model is a prototype, and we use it throughout the paper. The sociological studies all find that high-school students in the United States divide into social groups; they try to "fit in" to various categories, such as "jock," "burnout," and "nerd." Coleman's (1961) Adolescent Society established the relationship between such categories and achievement. His work followed August Hollingshead's Elmtown's Youth (1949), which found a strong correlation between students' class background and their behavior in school. Coleman derived students' social categories from survey questions such as "Would you say that you are a part of the leading crowd?" and prescriptions from questions such as "Among the crowd you go around with, which of the things below are important . . . : be a good dancer, have sharp clothes, have a good reputation, stir up a little excitement, have money, smoking, being up on cars, know what's going on in the world of popular singers and movie stars." 23,24

These categories and prescriptions for the "leading crowd" were associated with students' self-images and academic performance. Students in the leading crowd appeared to have an enhanced self-image; they were only half as likely "to want to be someone else" as other students. ${ }^{25}$ Their

\footnotetext{
${ }^{23}$ See Coleman (1961, Boys' Fall Questionnaire, p. 3). Another example: "Now rank the following four items in terms of their importance to you: groups and activities outside school, activities associated with school, having a good time, a good reputation." (p. 2).

${ }^{24}$ Coleman's categories were derived from answers to questionnaires; thus there remains some question as to the extent to which his social categories were imposed by the researcher; but later ethnographic studies of high schools show clearly Coleman's categories correspond to students' own classifications.

${ }_{25}$ Coleman (1961, p. 225).
} 
self-categorization seems to have affected their behavior. In schools where academic performance was not a criterion for being in the leading crowd, high-IQ students reduced their performance: The best students were less likely to be those with the highest IQ. ${ }^{26}$

Many ethnographies have followed Adolescent Society in describing how school social settings affect behavior. Eckert's (1989) study of the "jocks" and "burnouts" in a high school on the outskirts of Detroit, for example, shows that students see themselves in terms of these social categories and behave accordingly. She reports jocks and burnouts as behaving differently: in "clothing, territory, substance use, language, demeanor, academic behavior, and activities." 27 Each of these behaviors signifies difference and opposition between the two groups. Jocks wear pastels, burnouts wear dark colors. Burnouts smoke, jocks abstain. Jocks hang out around the lockers and avoid the courtyard, burnouts hang out in the courtyard and avoid the lockers. ${ }^{28}$ More generally, jocks accept the school's authority; burnouts reject it.

To capture this behavior, we construct a model where students both choose effort in school and divide themselves into three social categories: leading crowd, nerds, and burnouts; the addition of nerds corresponds to the groupings found by Jere Cohen (1979) in a factor analysis of student questionnaire responses.

\footnotetext{
${ }^{26}$ A similar finding obtained when comparing boys and girls. Girls, for whom outstanding achievement was less socially valued than for boys, also had lower variation in grades. This finding suggests that, like a girl we know who cried after winning a math prize, the girls in Coleman's survey reduced their academic achievement. Nor does the composition of socioeconomic status for the different schools offer an explanation - since the importance of scholarship for membership in the leading crowd does not vary systematically with school socioeconomic status.

${ }_{27}$ Eckert (1989, p. 69).

${ }^{28}$ See Eckert (1989, p. 50, p. 51 ff, p. 58 and p. 53 ).
}

Consider a population of students normalized to size one. Each student has two exogenously given characteristics. The first is ability, $n_{i}$, that is, a complement to effort in the production of skills. The second is physical appearance, or "looks," $l_{i}$. Looks and ability are both independently and uniformly distributed on $[0,1]$. A student's marketable skills depends on effort $e_{i}$ and ability $n_{i}, k_{i}=k_{i}\left(n_{i}, e_{i}\right)=n_{i} e_{i}$. The pecuniary cost of effort is $1 / 2\left(e_{i}\right)^{2}$.

As for identity payoffs, prescriptions give the ideal characteristics for each social category $L$, leading crowd; $N$, nerds; and $B$, burnouts. The ideal $L$ has looks $l=1$; the ideal $N$ has ability $n=1$; and the burnouts do not have an ideal. ${ }^{29}$ Prescriptions also dictate ideal effort levels, with $e(N)>e(L)$ $>e(B)$. A student's self-image depends on her own category, $c_{i}$, and the extent to which her own attributes and behavior correspond to her category's ideals. A student for whom $c_{i}=L$ earns identity payoffs $I_{L}-$ $t\left(1-l_{i}\right)$, where $t$ is a positive parameter scaling the identity loss from $i$ s distance from her ideal. A student who sees herself as an $N$ earns $I_{N}-t\left(1-n_{i}\right)$. The ethnographies suggest that $I_{L}>I_{N}>I_{B}$ so that students in the leading crowd have a more rewarding self-image than nerds or burnouts. For convenience, we normalize the initial self-image of burnouts to zero, $I_{B}=0$. A student will lose utility $1 / 2\left(e_{i}-e\left(c_{i}\right)\right)^{2}$ for deviations from the prescribed effort for her respective category, $c_{i}$.

The parameter $t$ is critical to this and subsequent models. It measures how difficult it is for students with different ascriptive characteristics to fit in a group. That is, $t$ is proportional to the translation of ascriptive characteristics into social differences.

Together we have a utility function for a student $i$ who is, respectively, $L, N$, or $B$, as:

${ }^{29}$ It is straightforward to model endogenous ideals. E.g., suppose the ideal is the average of members of the group. The equilibrium ideal then emerges from students' decisions to join different groups. Similar results concerning effort in school obtain. 


$$
\begin{aligned}
& U_{i}(L)=p\left[w \cdot k_{i}-\frac{1}{2} e_{i}^{2}\right] \\
& +(1-p)\left[I_{L}-t\left(1-l_{i}\right)-\frac{1}{2}\left(e_{i}-e(L)\right)^{2}\right] \\
& U_{i}(N)=p\left[w \cdot k_{i}-\frac{1}{2} e_{i}^{2}\right] \\
& +(1-p)\left[I_{N}-t\left(1-n_{i}\right)-\frac{1}{2}\left(e_{i}-e(N)\right)^{2}\right] \\
& U_{i}(B)=p\left[w \cdot k_{i}-\frac{1}{2} e_{i}^{2}\right] \\
& \quad+(1-p)\left[-\frac{1}{2}\left(e_{i}-e(B)\right)^{2}\right]
\end{aligned}
$$

where $0 \leq p \leq 1$ denotes the weight on the pecuniary benefits and costs of effort.

To maximize utility, a student chooses a category and an effort level. The special case where $p=0$ describes behavior when students care only about their current social situation. Ethnographies suggest such a low value of $p$. In the West Texas High School described by Foley (1990, p. 101): "Most students came to school for extracurricular activities and the social scene." For all but a few "brains," academics was a side show. In the model, a student chooses her category to balance social status with "fitting in." A student with sufficiently low $l$ will reject the leading crowd. She loses $I_{L}$ but no longer suffers the loss $t\left(1-l_{i}\right)$. Students whose $n$ is less than $\left(1-I_{N} / t\right)$ and whose $l$ is also less than $\left(1-I_{L} / t\right)$ choose to be burnouts - they are unable to obtain positive utility either as a nerd or as a member of the leading crowd. For $p=0$, each student $i$ chooses effort to match the ideal for her chosen category $c_{i}^{*}$; that is, $e_{\mathrm{i}}^{*}=\mathrm{e}\left(c_{i}^{*}\right)$.

This analysis shows the contrast between the outcomes of a purely economic model and a purely sociological model. In the purely economic model, when $p=1$, average effort is $w / 2$ and skill aquisition is $w / 3$.
Here, when $p=0$, identity is the only determinant of the input of student effort, which is, on average ${ }^{30}$ :

$$
\begin{gathered}
\left(1-I_{N} / t\right)\left(1-I_{L} / t\right) e(B) \\
+\left[\left(I_{N} / t\right)\left(1-I_{L} / t+1 / 2\left(I_{N} / t\right)\right] e(N)\right. \\
+\left[I_{L} / t-1 / 2\left(I_{N} / t\right)^{2}\right] e(L) .
\end{gathered}
$$

Neither effort nor skill acquisition is determined by the wage, but by the social parameters: $I_{N}, I_{L}, e(B), e(N), e(L)$, and $t \cdot{ }^{31}$ For $I_{L}$ $>I_{N}$, there is a group of students with high $n$ but also high $l$ who are in the leading crowd despite high levels of academic ability. These high-ability students, just as in Coleman's schools, reduce their performance below their high-ability peers.

In (2), skill acquisition is not responsive to the wage, but is responsive to the degree of social difference, $t$, in a school. When $t$ is high, it is harder for students with low $l$ and $n$ to fit in as part of the leading crowd or as a nerd. Skill acquisition is low, since more students become burnouts and exert low effort. On the other hand, when $t=0$, all students are in the leading crowd, average effort is $e(L)$, and skill acquisition is $e(L) / 2$.

As we will see further below, the preceding model allows an assessment of school policies that affect social categories and prescriptions. Policies that change any of the social parameters will almost always have an effect on educational outcomes as long as $p$ is not equal to one. For example, let us modify the model slightly to demonstrate the effect of school athletic programs, perhaps the most pervasive American school policy that affects students' social arrangements. Foley's (1990) West Texas school, for example, accorded special importance to football, and football players were among the most popular students in

\footnotetext{
${ }^{30}$ Here we discuss only the interior (nonboundary) solutions.

${ }^{31}$ For intermediate values of $p$, of course, skill acquisition will depend on both the pecuniary returns to education and the social structure of the school.
} 
school, as Coleman found, statistically, that being on the football team dramatically affected a boy's probability of being in the "leading crowd." 32 Let each student have an athletic ability $a_{i}$ that is independently and uniformly distributed on $[0,1] .{ }^{33}$ The ideal for an athlete is $a=1$, and athletes are members of the leading crowd (earning identity payoffs $I_{L}-t\left(1-a_{i}\right)$, and suffering $1 / 2\left(e_{i}-e(L)\right)^{2}$ for deviations from the ideal effort $e(L))$. With the additional choice of "athlete," some students with high academic ability, $n$, but with high $a$, join the leading crowd. Students with low $l$ and $n$ but with high $a$ also choose to be athletes. That is, athletics allows an entree into the leading crowd. Athletics turns some nerds into "jocks" and some burnouts into jocks. The effect on average skills may be either positive or negative, but unambiguously, there are fewer students in the two extreme categories. In this way, school athletic programs "democratize" skill acquisition. This outcome corresponds to the description of Foley's school, where working-class Mexican-Americans found their way into the leading crowd by excelling at football. The Mexican-American players were mostly from "low white collar" (54 percent) or "blue collar" families (20 percent), but they were much more likely than their peers to pursue a college education and to end up in middle-class jobs. ${ }^{34}$

\subsection{Empirical Evidence and High School and Beyond}

Here, as elsewhere in the paper, we shall discuss some of the empirical implications of our model that differentiate it from more traditional economic analysis of education. The model implies: first, there are different groups (or social categories); second, members of these different social categories have

32 See Coleman (1961, figure 4.10, p. 131).

33 Hollingshead (1975) found that athletic participation was positively correlated with social class. See also Coleman (1961).

${ }^{34}$ See Foley (1990, p. 138 and tables 2 and 4, pp. 232-33). different prescriptions; third, members of the different social categories will have different behaviors, predictable from the prescriptions; and fourth, school policies can change the divisions into social categories and prescriptions and thereby affect behavior.

The testing of each implication is challenged by a problem of identification. How can we know that being in one social category or another reflects anything more than individual tastes and endowments? For example, there may be no such thing as a group of nerds: those who are called nerds may just be those who are smarter and more academically inclined. The empirical task is to establish that membership in a social category, independent of tastes, affects behavior.

The model suggests in principle how to test for the existence of social categories and their influence. In the model a student just on the margin of being in one category or another, for example, of being a nerd or a member of the leading crowd, will have discontinuous effort, depending upon whether she chooses to be a nerd or in the leading crowd. With data on "looks" and "ability" as independent variables, and "effort" as the dependent variable, and with assumptions about the distributions of error terms, it would be possible to estimate the parameters of the model. Such an estimated model is identified by the nonlinearity in the behavior of effort, which will behave discontinuously at the boundary between social categories. But the potential presence of unobservables poses serious problems in interpreting such nonlinear estimations in practice. Consider the simplest possible model, where effort depends only on ability, which has observed and unobserved components that are not perfectly correlated. Now suppose that the researcher tries to test the effect of group membership. She will use effort as a dependent variable to estimate the slope of effort on observed ability, and she will also estimate a parameter that gives the level of ability that divides the nerds from others. She will falsely accept the hypothesis 
of categorization because the observed effort will be correlated with unobserved ability. It will appear falsely to her that there are two groups, whereas in truth there is only one group, with effort only dependent on ability.

Despite these problems, such groupings must sometimes be identifiable. The most prominent division of social category is universally known and is commonly used by econometricians. This is the division of the population by gender. A common econometric exercise is to check whether men and women behave differently. Tests of difference in behavior by gender avoid the problem of identification because the econometrician can take as given the categorization of male and female. In addition, the observation of membership in these two groups is made with almost no error. We propose that researchers use the same sort of information that accurately divides people into male and female to make other group identifications. The differences between male and female are unambiguous to almost all observers because men and women wish to signify their gender. Boys typically do not want to be classified as girls, nor girls classified as boys. They therefore signify their gender in a variety of ways that are obvious to each other and without ambiguity to any ethnographer. For groups that are less universal, econometricians need to use ethnographic information that provides the signifiers, for example, on dress and adomment whereby members of the different social groups indicate their membership, to themselves and to others. The description of the differences between jocks and nerds described by Eckert suggests the existence of such markers. Like males and females, they dress differently, they adom themselves differently, they have different manners and mannerisms. Since these signs are supposed to be read by others, there should be relatively little error, as in gender identification, as to how the groups are divided.

It is useful here to give a taste of Coleman's empirical strategy since it illus- trates the combination of being part ethnographer, part statistician. His analysis shows that different school groups within schools and across schools have different prescriptions. He first identifies members of the school elites by asking students who they "want to be like," or, alternatively, who is in "the leading crowd." 35 He then teases out the prescriptions by asking about the qualities of those in the elites and also how they differ from the rest of the student body. For example, he shows that members of the football team are much more likely to be in the elite ${ }^{36}$ they also have better grades. ${ }^{37}$ Among girls, the elites are much more likely to value participation in school activities, and somewhat more likely to want to be popular. ${ }^{38}$ He describes in some detail how the prescriptions of elites differ from those of the rest of the student body, how prescriptions differ by sex, and how they differ school-to-school by, for example, comparing the role of car ownership, the role of popular songs and movies, the role of reputation, and the factors making for popularity. ${ }^{39} . \mathrm{He}$ shows that there is consistency of opinion in many different questions, as would be expected if schools have a common understood culture. For example, there is a high correlation-not among freshman, who have just arrived, but among seniors-in ranking the role of high grades as a determinant of popularity and also of membership in the leading crowd. ${ }^{40} \mathrm{He}$ shows that in two schools that place special emphasis on intellectual activities, boys and girls both place especially high ranking on grades as a determinant of popularity. ${ }^{41}$ He views this finding

\footnotetext{
${ }^{35}$ Coleman (1961, pp. 6, 12). More precisely, the leading crowd was defined by answers to the following question: "If a fellow (girl) came here to your school and wanted to get in with the leading crowd, what fellows (girls) should he (she) get to be friends with?"

${ }^{36}$ Coleman (1961, p. 131)

${ }^{37}$ Coleman (1961, p. 82).

${ }^{38}$ Coleman (1961, p. 137).

39 Coleman (1961, ch. IV, pp. 97-142).

${ }^{40}$ Coleman (1961, p. 74).

${ }^{41}$ Coleman (1961, p. 78).
} 
TABLE 1

attitudes of Students by Social Category: Odds Ratio from Logit Regressions

\begin{tabular}{|c|c|c|c|c|c|}
\hline $\begin{array}{l}\text { Dependent } \\
\text { Variable: } \\
\text { Social Category }\end{array}$ & $\begin{array}{c}\cdot \\
\text { Positive Attitude } \\
\text { Toward Self }\end{array}$ & Depressed $^{f}$ & $\begin{array}{c}\text { Think I Am } \\
\text { No Good At Alls }\end{array}$ & $\begin{array}{c}\text { School Spirit } \\
\text { Excellent }^{h}\end{array}$ & $\begin{array}{c}\text { View School } \\
\text { Discipline as Fair }\end{array}$ \\
\hline $\begin{array}{l}\text { Nerds }{ }^{\mathrm{a}} \\
\mathrm{N}=19018\end{array}$ & $\begin{array}{l}1.32^{* *} \\
(.03)\end{array}$ & $\begin{array}{l}.74^{* *} \\
(.04)\end{array}$ & $\begin{array}{l}.80^{*} \\
(.03)\end{array}$ & $\begin{array}{c}.99 \\
(.02)\end{array}$ & $\begin{array}{l}1.33^{*} \\
(.05)\end{array}$ \\
\hline $\begin{array}{l}\text { Athletes }^{\mathrm{b}} \\
\mathrm{N}=25528\end{array}$ & $\begin{array}{l}1.37^{*} \\
(.03)\end{array}$ & $\begin{array}{c}.65^{*} \\
(.03)\end{array}$ & $\begin{array}{l}.95 \\
(.03)\end{array}$ & $\begin{array}{l}1.33^{* *} \\
(.03)\end{array}$ & $\begin{array}{l}1.21^{* *} \\
(.04)\end{array}$ \\
\hline $\begin{array}{l}\text { Leading Crowd } \\
\mathrm{N}=42230\end{array}$ & $\begin{array}{l}2.09^{*} \\
(.05)\end{array}$ & $\begin{array}{l}.46^{*} \\
(.02)\end{array}$ & $\begin{array}{l}.50^{*} \\
(.02)\end{array}$ & $\begin{array}{l}1.33^{* *} \\
(.03)\end{array}$ & $\begin{array}{l}1.19^{*} \\
(.05)\end{array}$ \\
\hline $\begin{array}{l}\text { Burnouts }^{\mathrm{d}} \\
\mathrm{N}=9279\end{array}$ & $\begin{array}{l}.93^{*} \\
(.02)\end{array}$ & $\begin{array}{l}1.75^{*} \\
(.08)\end{array}$ & $\begin{array}{l}1.88^{* *} \\
(.07)\end{array}$ & $\begin{array}{l}.90^{* *} \\
(.02)\end{array}$ & $\begin{array}{l}.76^{* *} \\
(.04)\end{array}$ \\
\hline
\end{tabular}

Source: High School and Beyond. ${ }^{\mathrm{a} N e r d: ~ t o o k ~ a d v a n c e d ~ E n g l i s h ~ o r ~ a d v a n c e d ~ m a t h ~ c o u r s e ; ~}{ }^{\mathrm{b}}$ Athlete: participated in varsity sports if senior, in varsity or other athletic teams, if junior; ${ }^{\mathrm{c}}$ Member of Leading Crowd: Regards self as pop-

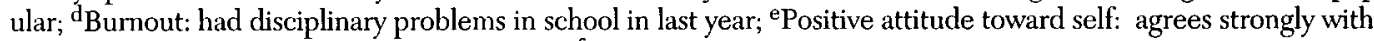
statement "I take a positive attitude of myself"; fDepressed: Respondents (sophomores only) felt depressed or unhappy a lot in past few weeks; 5Think I am no good at all: Strong agreement with statement "At times I think I am no good at all"; hespondent rates school spirit as excellent; ${ }^{i}$ Respondent rates faimess of discipline as excellent;

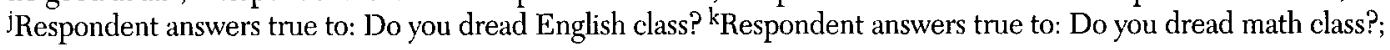

as the result of a small natural experiment (of course with undetermined problems of selection bias) that those who are placed into different school environments will end up with different prescriptions.

Although a researcher could use cross section data in the fashion of Coleman, panel data is necessary to test the model against the possibility that the observed correlations are merely due to the correlation between group membership and unobserved tastes. The two cases have very different policy implications. If the model describes reality, the shift of a person from one group to another will result in a change in their prescriptions and their behavior. If, on the other hand, the correlation between prescriptions and group behavior are only due to unobserved tastes, such shifts will have no effect on behavior. Indeed, to test for one of these possibilities relative to another, one needs panel data where the shift from one category to another was randomly distributed, as in either a controlled or a natural experiment. We defer the discussion of such data until later in the paper, after we have seen some effects of different educational experiments. We will find that there may be natural and controlled experiments that could be used to test some of the predictions of the model.

We ourselves engaged in a crude attempt to see whether behavior is associated with social category. Adolescent Society was not only followed by ethnographies, but also by the construction of a large data set, High School and Beyond. The questionnaires of Adolescent Society and High School and Beyond, which is the source for our tables, are strikingly similar, including questions about self-esteem and membership in the leading crowd. The problems with these tables serve as a useful backdrop for discussion of the needs of empirical 
TABLE 1 (cont.)

\begin{tabular}{cccccc}
$\begin{array}{c}\text { Dread English } \\
\text { Class }\end{array}$ & $\begin{array}{c}\text { Dread Math } \\
\text { Class }^{k}\end{array}$ & $\begin{array}{c}\text { Take ACT or } \\
\text { SAT }^{1}\end{array}$ & $\begin{array}{c}\text { Bored a } \\
\text { Lot }^{\text {m }}\end{array}$ & $\begin{array}{c}\text { Like Working } \\
\text { Hard at School }^{\mathbf{n}}\end{array}$ & $\begin{array}{c}\text { Disappointed if Do } \\
\text { Not Go to College }^{\circ}\end{array}$ \\
\hline $.64^{* *}$ & $.68^{* *}$ & $2.24^{* *}$ & $.84^{* *}$ & $1.82^{* *}$ & $2.34^{* *}$ \\
$(.02)$ & $(.02)$ & $(.06)$ & $(.03)$ & $(.03)$ & $(.05)$ \\
$.90^{* *}$ & $.86^{* *}$ & $2.79^{* *}$ & $.77^{* *}$ & $1.16^{* *}$ & $1.58^{* *}$ \\
$(.02)$ & $(.02)$ & $(.07)$ & $(.02)$ & $(.02)$ & $(.03)$ \\
$.71^{* *}$ & $.92^{* *}$ & $1.28^{* *}$ & $.58^{* *}$ & $1.41^{* *}$ & $1.50^{* *}$ \\
$(.02)$ & $(.03)$ & $(.03)$ & $(.02)$ & $(.03)$ & $(.03)$ \\
$1.75^{*}$ & $1.50^{* *}$ & $.86^{* *}$ & $1.47^{* *}$ & $.49^{* *}$ & $.54^{* *}$ \\
$(.06)$ & $(.05)$ & $(.02)$ & $(.05)$ & $(.01)$ & $(.01)$ \\
\hline \hline
\end{tabular}

${ }^{\text {'ACT }}$ or SAT: seniors only; " Bored a lot: Respondent felt bored a lot in last few weeks; "Working hard at school: respondent likes working hard at school; ${ }^{\circ}$ Disappointed if do not go to college: agreement with statement "I will be disappointed if I do not go to college." a, b, c, d are the dependent variables; each of them is regressed on the independent variables ( $\mathrm{e}, \mathrm{f}, \mathrm{g}, \mathrm{h}, \mathrm{i}, \mathrm{j}, \mathrm{k}, \mathrm{l}, \mathrm{m}, \mathrm{n}, \mathrm{o}$ ) one-by-one; standard errors are in parentheses; " indicates significant at $1 \%$ significance level. Example: Odds Ratio $(\mathrm{OR})=$ Odds for depressed(Nerd)/Odds for depressed (non-Nerd) = .74; where Odds for depressed $=$ probability of depressed/probability of not depressed; logit $(p)=a+b X ; O R=e^{b}$.

work that tries to "test" our model and shows the need for data at an ethnographic or nearethnographic level.

Table 1 categorizes students who reported taking advanced English or math classes as "nerds;" students on sports teams as "athletes;" those who responded "yes" to "are you a member of the leading crowd in your school?" as in the "leading crowd," and those who reported disciplinary problems as "burnouts." The nerds, athletes, and members of the leading crowd appear to have better opinions of themselves than students outside these respective categories. They were more likely to agree strongly with the statement "I take a positive attitude of myself;" less likely to be "depressed or unhappy a lot" in the past few weeks; and less likely to agree with the statement "I think I am no good at all." Burnouts show the opposite pattern. Similarly, as in the model, athletes, nerds, and members of the leading crowd appear to show more positive attitudes toward school than students outside their respective category. Table 1 shows that they were considerably less likely to view school discipline as poor; less likely to have been bored a lot; more likely to be disappointed if they do not graduate from college; and more likely to like working hard in school. Burnout attitudes had the opposite pattern. These observations are consistent with the premise of our model that athletes, nerds, and the leading crowd all identify with school; burnouts reject it. In table 2 we see that burnouts are less likely to be from the top quintile of socioeconomic status (SES) and considerably more likely to be from the bottom quintile than non-burnouts, and the opposite pattern describes the SES of athletes, nerds, and members of the leading crowd. 
TABLE 2

Socioeconomic Status of Parents and Social Category: Odds Ratio from Logit Regressions

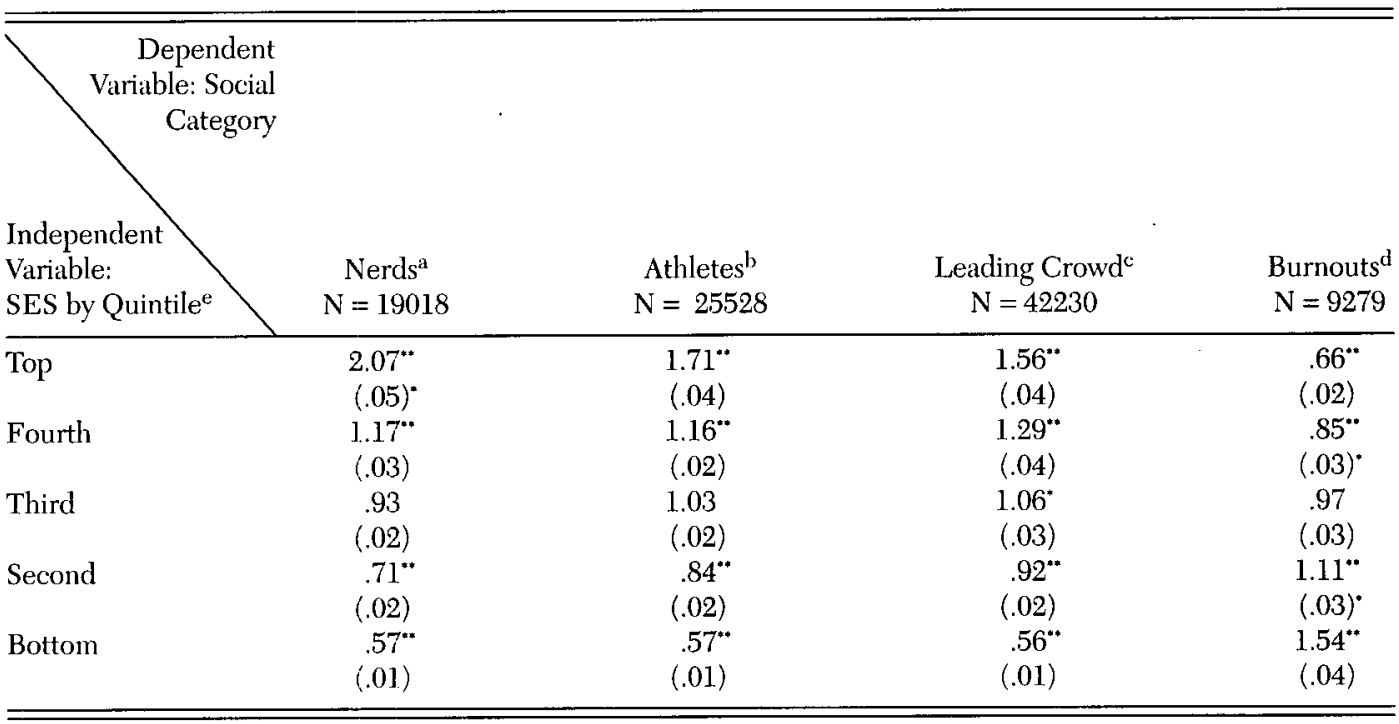

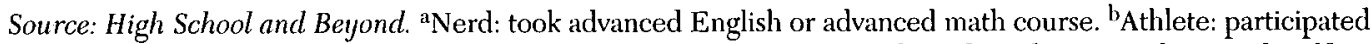
in varsity sports if senior, in varsity or other athletic teams if junior; ${ }^{c}$ Member of Leading Crowd: Regards self as

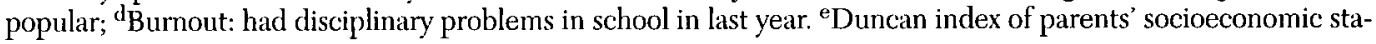
tus from parents' survey.

Standard errors are reported in parentheses; "Significant at $5 \%$ level; "significant at $1 \%$ level; example: Odds Ratio $(\mathrm{OR})=$ Odds for Nerd (bottom quintile)/Odds for Nerd (not from bottom quintile) $=.57$, where Odds for Nerd = probability of Nerd/probability of not Nerd; logit $(p)=a+b X ; O R=e^{b}$.

While tables 1 and 2 appear to substantiate our model's assumptions, other interpretations are equally consistent with the data. The leading problem of interpretation is in the classification of students by group. Consider our classification of "nerds." We have classified nerds by their behavior, as those who take an honors course. Irrespective of whether nerds form a social category that will affect their attitudes toward academic work, we might also expect those who have tastes for taking such courses to have all of the attitudes attributed to them in the table, such as "positive attitude toward self," unlikely to be "depressed," unlikely "to think I am no good at all," etc. The same can also be said of burnouts and athletes. Our definition of "leading crowd" yields another problem: this is a self-classification; at best it reflects the perception of the interviewee. She may be overly optimistic about her position or she may be knowingly stretching the truth. We would expect that both over-optimists and truth-stretchers give much the same answers as those who are true members of the leading crowd. The problems with the interpretation of the groups in tables 1 and 2 confirm the importance of systematic means outside the questionnaire to classify groups, as we suggested could be done by the marriage of ethnographic observation and statistical use of questionnaires.

\section{The School as an Institution}

To many scholars outside economics, schools are social institutions with social goals. Schools not only impart skills; they impart the characteristics and behavior of ideal students. Here we discuss this second aspect 
of the sociological approach to education that is missing from current economic modeling. In this approach, students' identities delineate whether a student accepts or rejects the school itself. We have already seen Eckert's description that a primary division between jocks and burnouts is that jocks accept the school and participate in its activities, while burnouts reject it.

Why would students reject their school? A large part of the sociology of schooling points to systematic social differences between students and schools as a reason. Histories of urban education, for example, emphasize the clash between the Americanizing schools of the early twentieth century and their immigrant students. Students were not just taught reading, writing, and arithmetic. In school, they were also corrected in details of comportment, including what to wear and how to speak. ${ }^{42}$ The teachers believed they were teaching the students what they needed to be economically successful. The skills were socially neutral-just logic and reason. ${ }^{43}$ But that is not how it seemed to all students. One protagonist, quoted prominently by Robert Hampel (1986), relates that his loving English teacher disapproved of his clothing and manners and saw him as a "filthy little slum

42 According to David Tyack's (1974, p. 234) history, turn-of-the-century public schools demanded "total assimilation ... [and] creat[ed] a sense of shame at being 'foreign." See also Hampel (1986).

${ }_{43}$ Bloom (1987, p. 27) characterizes the social category whence immigrant students were being rescued as that of the "traditional communities where myth and passion as well as severe discipline, authority, and the extended family produced an instinctive unqualified, even fanatic patriotism." He contrasts this with the ideal of the schools: "the rational and industrious man, who was honest, respected the laws, and was dedicated to the family . . . Above all he was to know the rights doctrine; the Constitution, which embodied it; and American history, which presented and celebrated the founding of a nation conceived in liberty and dedicated in the proposition that all men are created equal." For the purposes of this paper it does not matter whether Bloom has given the correct interpretation of the contrasts; all that matters is that the protagonists believed in these differences. child." This episode shows the culture clash emphasized by education historians, that even the most caring teachers can unknowingly offend their students and convey that they are inferior.

In our modeling below, schools face a tradeoff that captures the historical and ethnographic accounts of schooling in the United States. These accounts, and our model, see the school as having a choice between promoting a student ideal closer to economically useful cultural norms and skills and an ideal closer to the students' social backgrounds. ${ }^{44}$ It may seem strange to an economist that such a trade-off exists. But sociologists' accounts reveal that skills, and certainly norms of dress and comportment, are not socially neutral. Even such skills as proficiency in English and mathematics are associated with particular social categories, and a curriculum can privilege certain social groups. In this case, the promotion of certain skills and prescriptions for behavior can alienate students from different social backgrounds.

Paul Willis' (1977) classic day-to-day account of working-class British adolescents illustrates. To Willis, the school itself, as an

\footnotetext{
${ }^{44}$ Bowles, Gintis, and Melissa Osborne (2001) discuss the extent to which schooling increases earnings by affecting personality. Curiously, the inclusion of measures of cognitive ability in earnings equations reduces the coefficient on schooling relatively little-taking an average over different studies, by only 18 percent. (See p. 1149). Personality seems to matter more. For example, in an earnings equation with PSID data the introduction of a battery of motivational and behavioral traits reduces the coefficient of years of schooling on earnings by 37 percent (see p. 1164). These results, and others, are suggestive (although certainly not conclusive) that behavioral traits developed in school are important components of the school-based skills that are of economic advantage. Exactly consistent with these results and the argument in this section, Bowles, Gintis, and Osborne hypothesize that much of the economic benefit of schooling results from "subjecting students to types of social interactions and systems of reward that replicate the social interactions and reward systems of the workplace, providing positive reinforcement for some behaviors and personalities and sanctions for others" (p. 1167)
} 
institution, embodies a set of prescriptions, derived from teachers who value order and discipline, as well as the administration that sponsors programs to "reform" workingclass youth. Willis' account shows students' powerful reactions to such school messages. He follows a group who call themselves "the lads," who resist schooling and end up, like their parents, in working-class jobs. The lads' opposition to the school can be found in almost everything they do. They break school rules by drinking, smoking, disrupting class, and, especially, by generating a "laff" (practical joke). Their clothes suggest sexual maturity, just as smoking and drinking indicate their rejection of school rules meant for children. Just prior to graduation, the lads got drunk at a pub at lunch time and returned to school, where the school authorities punished them by refusing to let them graduate. Teachers were surprised at the lads' spree because they could have waited until the evening to drink. The teachers missed the symbolism of the lads' last "laff."

In other ethnographies, we see that the lads behave like "burnouts" everywhere. Foley (1990) relates a similar West Texas example of resistant behavior by MexicanAmerican male high-school students. ${ }^{45}$ Foley relates hitching a ride with some "vatos" to an away football game. As the boys light up joints on the way, they plan to chase the local girls and provoke a fight with the local males, thereby using a "respectable event to be disrespectful, rebellious and cool." 46 Just as the lads use their school's rules against alcohol and smoking as the context for their displays, the vatos use their school's preoccupation with football as the backdrop for their resistance.

Willis and Foley see it as no coincidence that the lads and the vatos come from working-class families. To them, the schools are

\footnotetext{
45 For Mexican Americans, see also Angela Valenzuela (1999). Signithia Fordham (1996) provides a study of African-American students.

${ }^{46}$ Foley (1990, p. 58).
}

insulting. The only vato who made it into the middle class ${ }^{47}$ reflected, ten years later, on his high-school experience. In his comments we see the key features of the models that follow-the anger at teachers and school and the corresponding social divisions, with some students accepting the school and others rejecting it:
We were really angry about the way the teachers treated us. They looked down on us and never really tried to help us. A lot of us were real smart kids, but we never figured that the school was going to do anything for us . . We were the vi- olent macho types, I guess. They'd [the teach- ers] manipulate the nerds into school and books. There was a real separation between us and the nerds and the jocks. ${ }^{48}$

A sequence of three models will capture the historical development of U.S. schools in the twentieth century. The first model captures historians' depiction of the initial period, in the early twentieth century: schools have a single ideal, which students may accept or reject. The second model conforms to the sociological picture of contemporary public education: schools adjust to their diverse student bodies by allowing students to choose among different ideals within the same school. The third model captures the nature of reform programs: schools reduce the social difference between students and their schools; students then identify with these schools, which promote high academic achievement.

In our review, rules and disciplinary processes will appear prominently as evidence of the ideals and prescriptions of schools. Sociologists view such observations as especially revealing. In his study of the Puritans, Kai Erikson (1966) observed that rules and disciplinary proceedings delineate the boundaries of a community. Punishment is an occasion to draw the line between acceptable and unacceptable behavior. Accordingly, those who willingly disobeyed the rules are not full members of the community. In the school

${ }^{47}$ Foley (1990, p. 140).

${ }^{48}$ Foley (1990, p. 139). 
context, we have already seen how the lads and the vatos used disobedience of school rules to demonstrate their rejection of the school and its ideals.

\subsection{A Model of a School with a Single Ideal}

A model with a single ideal reflects historians' view of late nineteenth- and early twentieth-century U.S. public schooling. Associated with the school is a social category, which we label $S$. The school's prescriptions give the ideal characteristic and behavior of a student in this category. Suppose students' characteristics $\varepsilon_{i}$, such as class, ethnicity, or other social attributes, are uniformly distributed on $[m-\sigma / 2, m+\sigma / 2]$, where $m$ is the mean and $\sigma$ represents the diversity of the student population. ${ }^{49}$ Let $s \in$ $[m-\sigma / 2, m+\sigma / 2]$ denote the ideal characteristics of $S$, and let $e(S)>0$ denote the ideal effort level. We call $s$ the school's ideal.

As in the model of the previous section, a student's self-image depends on her category and the extent to which her own attributes and behavior match the ideals for her category. A student $i$ who identifies with the school category, $S$, earns $I_{S}-t\left(s-\varepsilon_{i}\right)$ for $\varepsilon_{i} \leq$ $s$ and earns $I_{S}$ for $\varepsilon_{i}>s$. The parameter $t$ again measures the extent to which students with different characteristics do not fit the school's category. A student suffers an identity loss $1 / 2\left(e_{i}-e(S)\right)^{2}$ for diverging from the ideal effort level $e(S)$. A student $i$ who does not identify with the school, a "(B)urnout," earns identity payoffs $d_{i} I_{B}$ where $0 \leq d_{i} \leq 1$ is the level of student $i$ s

\footnotetext{
${ }^{49}$ Students' characteristics $\varepsilon$, in general, can include a variety of traits. Some will be correlated with a family's socioeconomic status, race, and ethnicity. Others will be purely idiosyncratic. Most economic models consider idiosyncratic traits as tastes, randomly distributed in the population. In our setting, these traits reflect a student's social background. We consider how these socially defined traits affect effort in school. Idiosyncratic components would explain the differences in outcomes within social groups. For instance, there are "burnouts" even at all-white middle- and upper-class schools. A poignant fictional example, J.D. Salinger's Holden Caulfield, speaks in the voice of a burnout.
}

disruption in the school. This disruption expresses an alternative identity, as seen in the behavior of the lads and the vatos. A $B$ will also lose utility of $1 / 2\left(e_{i}-e(B)\right)^{2}$ for deviating from the prescribed effort level $e(B)$, which we normalize to zero.

We assume that the school ideal, $s$, affects marketable skills. In particular, the greater is $s$, the more marketable skills a student obtains for a given effort level. This assumption reflects associations between certain social categories and the curriculum, behavioral prescriptions, and other aspects of economic success. Let the production function for skills take the form $k_{i}=s e_{i}\left(1-d_{i}\right)$, where skills are increasing in $s$ and $e_{i}$ but decreasing in disruption $d_{i}$. With these assumptions, an $S$ and a $B$ have utility, respectively,

$$
\begin{aligned}
& U_{i}(S)=p\left[s \cdot e_{i}-\frac{1}{2} e_{i}^{2}\right] \\
& +(1-p)\left[I_{S}-\frac{1}{2}\left(e_{i}-e(S)\right)^{2}\right] \text { for } \epsilon_{i}>s \\
& =p\left[s \cdot e_{i}-\frac{1}{2} e_{i}^{2}\right] \\
& +(1-p)\left[I_{S}-t\left(s-\epsilon_{i}\right)-\frac{1}{2}\left(e_{i}-e(S)\right)^{2}\right] \\
& U_{i}(B)=p\left[s \cdot e_{i}\left(1-d_{i}\right)-\frac{1}{2} e_{i}^{2}\right] \\
& +(1-p)\left[d_{i} \cdot I_{B}-\frac{1}{2}\left(e_{i}-e(B)\right)^{2}\right] .
\end{aligned}
$$

As previously, the special case $p=0$ is the pure sociological model. In this case, any student who does not identify with the school will choose $d_{i}=1$. The number of burnouts is determined by the position of the school, $s$, relative to the distribution of the students, and the relative gain of identifying with 
school $I \equiv I_{S}-I_{B}$. Let $\beta$ denote the fraction of burnouts. We have

$$
\beta=\frac{1}{2}+\frac{s-m-I / t}{\sigma}
$$

and mean skill acquisition, denoted as $K$, of

$$
K=s \cdot e(S) \cdot\left(\frac{1}{2}-\frac{s-m-I / t}{\sigma}\right)
$$

For $s$ sufficiently above the median student, $K$ declines in $s$ even though higher $s$ contributes directly to skill acquisition. As $s$ increases, more students reject the school, reducing the total skill level. The parameter $t$ is critical. The greater is $t$, the greater the social differences between the students and the school. For a given $s$, as $t$ increases, more students reject the school, and skills decline. ${ }^{50}$

\subsection{Hamilton High to Shopping Mall High}

The modeling above captures events at "Hamilton High," events that sociologists believe reflect general trends in U.S. education. The World We Created at Hamilton High by Gerald Grant (1988) gives a detailed account of an upstate New York high school from the 1950s to the 1980s. This history relates a great deal of discord-even the closure of the school for some period of time. It also relates how the school came back together as a place of learning. To an economist Hamilton High seems to be only a curious story: it does not fit into the typical model. There is massive change in educational outcomes, but no change in resources. Shifts in parameters of the model here, however, easily capture Grant's history of the school.

In the 1950s and early 1960s, Hamilton High's student population was homogeneous ( $\sigma$ was small) and its ideal, $s$, was in the center of the population of white middle-class

\footnotetext{
${ }^{50}$ Here, as before, the text describes the nature of interior solutions.
}

students. The school's prescriptions were clear. The principal had few doubts that his job was to "enforce middle-class standards of courtesy and respect, emphasize a college preparatory curriculum and put winning teams on the Hamilton field." 51 Students actively participated in the school activities, in the newspaper, Greek letter fraternities and sororities, the girls' club, and the a capella chorus, and such.

Grant then relates what happened after a significant number of poor black students entered the school in the late 1960s under orders of forced integration. In terms of our model, the diversity, $\sigma$, of the students rose; most of the new students' characteristics were considerably below the school's ideal $s$. The model predicts exactly what happened: the number of burnouts and the disruption in the school increased. The new students reacted almost immediately to rejection by the white students and the faculty. ${ }^{52}$ Day-today there were clashes, arising from what black students and their parents saw as racism and unfair application of school rules. The following interaction was a typical classroom exchange:

Teacher (to black student): Please sit down and stop talking.

Student: I was only seeing if I could borrow a pencil and a piece of paper for that quiz you were talking about.

Teacher: You know you're supposed to be in your seat.

Student: But you will give me a zero if I don't have a quiz paper.

Teacher (slightly exasperated): Sit down. You're supposed to bring those things to class or borrow them before class.

Student (voice rising): Why you picking on me? You don't pick on white kids who borrow a piece of paper. ${ }^{53}$

Anger rose to the point that riots closed the school. The riots began after a fraternity party behind the school where white students told a group of blacks to "get out of

${ }^{51}$ Grant (1988, p. 241).

${ }^{52}$ For changes in $\sigma$ holding constant the upper bound $m+\sigma / 2$, the number of burnouts, $\beta$, is increasing in $\sigma$.

${ }^{53}$ Grant (1988, p. 36). 
our school." The next Monday, some of the new students tore up the school cafeteria. A chemistry teacher summarized students' feelings:

The black students were responding to the way they were being treated. You know, it's like these white teachers don't really care anything about me . . . He isn't teaching me anything. You know, it's a handout sheet every day or it's a film everyday. The teacher may be making racist remarks overt or subtle. . .54

The principal of the school looking back at the period said: "[the school] gave them the message that 'some people did not belong." "55

As the story of Hamilton High continues, we see the school adjusting to its diverse student body. Gradually, the school of Greekletter clubs and a capella choruses faded away. A new school emerged, whose defining features were tolerance and students' rights to choice ${ }^{56} \mathrm{~A}$ slightly revised model below captures this new Hamilton High, which is similar to what has been elsewhere described as the typical contemporary U.S. high school, Shopping Mall High (Powell et al. 1985).

\subsection{A Model of Shopping Mall High}

In Hamilton High, as in other schools throughout the country, students in the 1970s were granted greater rights. Gone were the days of unquestioned in loco parentis and a consensus on the school's ideals. ${ }^{57}$ At Hamilton High, new rules essentially eliminated teachers' authority to enforce academic and other behavioral standards.

${ }^{54}$ Grant (1988, p. 35).

55 Grant (1988, p. 38).

56 The problems at Hamilton High are an extreme version of the day-to-day struggle to maintain school order. Everhart, along with Willis (1977), Foley (1990), Lois Weiss (1990), and others, paint a remarkably similar picture of the many small and large ways students assert themselves against teachers' authority, disrupting class and school operations. When students do not identify with the school and accept its authority, learning does not occur.

${ }^{37}$ We discuss in detail below the legal innovations that advanced students' rights.
Arbitration guidelines, adopted in 1972, allowed students to initiate grievance procedures "when the behavior of any staff member willfully imposes upon a student the ethical, social or political values of the staff member." 58 Teachers only rarely corrected student behavior, inside or outside the classroom. A teacher who asked a repeatedly tardy student to bring a note from home when late was told by the parent: "stop worrying my child just because you have a middle-class hang-up about time." 59 Teachers who tried to punish students for cheating often had to defend their allegations to the principal, to the student's parents, and, when called upon, to the student's lawyers.

Students also gained rights to choose their curriculum. The school instituted more elective courses; only ten of eighteen credits required for graduation were specified. Even though formal tracking was eliminated, students now tracked themselves. Those interested in academics sought out the best teachers, and those not interested chose less challenging courses. As the school turned to laissez faire, the troubles died down. Learning took root again, but the previous standards no longer applied.

Grant's description of the new Hamilton High conforms to educators' description of typical U.S. high schools across the country (Hampel 1986). Powell et al. (1985) call these high schools "shopping malls," where students are treated as customers. The schools give them what they want, making little or no attempt to change their values. The Shopping Mall High School appears not to be just the result of changes in the 1960s as reported by Grant and Hampel, but rather to be the much longer evolutionary outcome of continued democratization of U.S. schools. This democratization was even more dramatic earlier in the century (see Katz and Goldin 1997), especially as "life

\footnotetext{
${ }^{58}$ These guidelines were distributed to all students in a handbook outlining their rights (Grant 1988, p. 53). ${ }^{59}$ Grant (1988, p. 54).
} 
skills" curricula were introduced for the non-college-bound who were said to be "preparing for life." 60

We now capture the essence of a Shopping Mall High School in a model where a school may adjust to its student population. The school has two options. It can select a single ideal. Alternatively, the school can give the students a choice between two ideals. The school makes this selection to maximize the total skills, $K{ }^{61}$ The analysis shows each of the school's options in turn, then determines which of the two options is optimal.

Single-s optimum. Recall that $K$ takes into account students' choices whether or not to identify with the school. As we have already seen, $K=s \cdot e(S) \cdot[1-\beta]$, where $\beta$ is the fraction of burnouts. The choice of $s$ involves a trade-off: Increasing $s$ increases skills directly, but reduces $[1-\beta]$, the number of students who identify with the school. The optimal $s$ balances these effects. From (4) and (5) above, the optimal $s$ that maximizes $K$ is:

$$
s^{*}=\min \left[m+\frac{\sigma}{2}, \frac{1}{2}\left(m+\frac{\sigma}{2}+\frac{I}{t}\right)\right]
$$

Notice again the impact of the social parameter $t$; the optimal ideal $s^{*}$ is decreasing in $t$. The more students view themselves as different from the school, the more the school must reduce its ideal to engage students in the school and increase skills. ${ }^{62}$

\footnotetext{
60 This debate is well-documented in Edward Krug (1964) and (1972). Diane Ravitch (1983, p. 46) excoriates progressive educators, who championed nontraditional high school curricula, emphasizing life skills relating to health, vocation, and family and community life.

61 Certainly, a school administration could have other goals in choosing its category and prescriptions, as would be the case in religious schools. We discuss this possibility below.

${ }^{62}$ This level of $s$ is invariant to changes in $\sigma$ and $m$ when $m+\sigma / 2$ is held constant. The optimal school after integration at Hamilton High would be the same as the optimal school before integration. However, if we included the many externalities of disruption, the school would lower s to account for the new students.
}

Double-s Optimum. Consider now a school that can give students a choice. Instead of one ideal, the school can set two ideals $s_{\mathrm{H}}$ and $s_{\mathrm{M}}$, where $s_{\mathrm{H}}>s_{\mathrm{M}}$ and $s_{\mathrm{H}}$ is associated with higher academic achievement. There are now three social categories: (H)onors students, with ideals $s_{\mathrm{H}}$ and $e(H)$; (M)iddle students with ideals $s_{\mathrm{M}}$ and $e(M)$, and $(B)$ urnouts, with no ideal and ideal effort level $e(\mathrm{~B})$, where $e(H)>e(M)>e(B) \equiv 0$.

Middle students are a prominent category in Theodore Sizer's (1984) description of United States' public schools as well as Powell et al.ss Shopping Mall High School. These students are largely uninspired-to learn or to misbehave. They make their way to the end of their schooling, without being prompted to investigate, learn, or question. In Horace's Hope Sizer relates shadowing one such student, Martha, for the course of her school day. Passing from class to class, in which she is taught "pap [sic]," Martha maintains a mask of passivity.

As before, a student's identity depends on the match between own characteristics and behavior and the ideal of her category. A student $i$ choosing category $c_{i}=\mathrm{H}, \mathrm{M}$ earns identity payoffs $I_{S}-t\left(s_{c}-\varepsilon_{i}\right)-1 / 2\left(e_{i}-e\left(c_{i}\right)\right)^{2}$ for $\varepsilon_{i} \leq s_{c}$ and earns $I_{S}-1 / 2\left(e_{i}-e\left(c_{i}\right)\right)^{2}$ for $\varepsilon_{i}$ $>s_{c}$. Burnouts earn the identity payoffs of the previous model. We again consider students' choices of effort and category for $p=0 .{ }^{63}$ There will be $(1 / \sigma)\left(m+\sigma / 2-s_{\mathrm{H}}\right) \mathrm{H}$ students; $(1 / \sigma)\left(s_{\mathrm{H}}-s_{\mathrm{M}}+I / t\right) \mathrm{M}$ students; and $(1 / \sigma)\left(s_{M}-I / t-m+\sigma / 2\right)$ B's. Mean skills as a function of $s_{\mathrm{H}}$ and $s_{\mathrm{M}}$ are:

${ }^{63}$ Once again, the text concentrates on nonboundary solutions. $\varepsilon_{i}$ is again assumed uniformly distributed on the range $[m-\sigma / 2, m+\sigma / 2]$. An appendix available upon request gives the full specification and analysis of the model. In the analysis we assume that all students located above $s_{H}$ choose $\mathrm{H}$. For $s_{\mathrm{H}}=s_{\mathrm{M}}$, we assume that students located above $s_{\mathrm{H}}=s_{\mathrm{M}}$ choose $\mathrm{H}$ (and exert $e(\mathrm{H}))$ and students located below $s_{\mathrm{H}}=s_{\mathrm{M}}$ that choose to identify with a school choose $\mathbf{M}$ and exert $e(\mathbf{M})$. This assumption prevents a discontinuity in the numbers of $\mathrm{H}$ and $\mathrm{M}$ students at $s_{\mathrm{H}}=s_{\mathrm{M}}$. In what is written below, we assume $s_{\mathrm{M}}>m-\sigma / 2+I / t$. This assumption is without loss of generality because it is never optimal for the school to set $s_{\mathrm{M}}$ at a lower level. 


$$
\begin{aligned}
K=s_{\mathrm{H}}\left[\frac{1}{2}+\right. & \left.\frac{m-s_{\mathrm{H}}}{\sigma}\right] e(\mathrm{H}) \\
& +S_{\mathrm{M}}\left[\frac{s_{\mathrm{H}}-s_{\mathrm{M}}}{\sigma}+\frac{\mathrm{I}}{\sigma \cdot t}\right] e(\mathrm{M})
\end{aligned}
$$

When setting $s_{\mathrm{H}}$ and $s_{\mathrm{M}}$, the school faces two trade-offs. First, as with one category, raising ideals $s_{\mathrm{H}}$ and $s_{\mathrm{M}}$ directly increases skill attainment, but increases the number of burnouts. Second, there is competition between the categories. Increasing $s_{\mathrm{H}}$ increases the skills of the honor students, but more students will opt for the middle category, with lower educational attainment. An appendix provides the optimal $s_{\mathrm{H}}^{*}$ and $s_{\mathrm{M}}^{*}$ as functions of $I, m, \sigma$, and $t: s_{\mathrm{H}}^{*}$ and $s_{\mathrm{M}}^{*}$ are increasing in $m$ and $\sigma$, and decreasing in $t$. The distance $\left(s_{\mathrm{H}^{-}}^{*}\right.$ $\left.s_{\mathrm{M}}^{*}\right)$ increases with $t$ and $\sigma$.

Selection Between Single-s or Double-s School. When is it optimal for a school to give students a choice rather than to promote a single social ideal? The results match the historical accounts. Comparison of the total skills for one category, $s^{*}$, and of two, $s_{\mathrm{H}}^{*}$ and $s_{\mathrm{M}}^{*}$, shows that when the social distinctions are large ( $t$ is large or $\sigma$ is large), the school achieves higher skills by providing two categories. Two categories increases the number of students who identify with the school. When the social distinctions are small, ( $t$ is small or $\sigma$ is small), students are more likely to identify with the school, and a school will maximize skills by eliminating choice and providing a single standard. The events at Hamilton High are thus consistent with the model. In the short run, the single initial value of $s$ is fixed and there was massive disruption. This disruption eased in the long run as the school moved from a single-s ideal to a double-s ideal with choice and tolerance.

\section{Resource Use: Investments in Identity and School Reform}

In this section, we introduce resources into our modeling of schools. This exercise integrates the sociological view of schools with a classic economic view, and, we believe, captures the essence of contemporary school reform programs. In the previous generation, educators promoted large schools to take advantage of economies of scale; schools should be consolidated so as to offer a variety of advanced courses (James Conant 1959). Current school reform promotes small schools, with unified programs. We argue that school reform on both the left and the right can be characterized in this same way: reformed schools use resources to create a community, represented in the model as a reduction in the parameter $t{ }^{64}$ Students with low values of $t$ do not differentiate themselves from each other according to their home background. This leaves schools free to choose an $s$ leading to high skill acquisition.

\subsection{Central Park East Elementary and Secondary Schools}

Central Park East Elementary and Secondary Schools is a poster child for school reform and illustrates the value of creating a community and inducing students to identify with the school. There is no doubt about CPESS' success. In East Harlem, a neighborhood where students are more likely to go to jail than to college, this school has almost no dropouts; it sends 90 percent of its graduates on to college of whom 90 percent graduate. 65

Accounts of CPESS suggest that its success lies in students' and teachers' identification with the school and its academic ideals. This identification is no accident. From the very beginning, school administrators set out to create a new type of school, with a strong sense of community. The school takes students out of their troubled community and isolates them in a different world. The importance of creating a new, different social category is apparent to Deborah Meier, the founder-director. In her

\footnotetext{
${ }^{64}$ We could also model investments that change the distribution of students' characteristics. Similar results obtain. Reforms can also involve prescriptions for effort in school. We discuss disciplinary reforms below.

65 Indeed the school has been dubbed the "miracle in East Harlem" (Seymour Fliegel 1993).
} 
words: "We committed ourselves openly and loudly to being different." 66 She further emphasizes: 'We wanted no 'we' versus 'they' in this community." 67

The unusual pedagogy and arrangements at CPESS underlies the group identity of the school. The curriculum is generated by the ideas of students themselves, and examining these ideas systematically using "The Five Habits of Mind." These five habits require asking and answering: "How do we know what we know?" "Who's speaking?" "What causes what?" "How might things have been different?" and "Who cares?"68 The school's other practices help students identify with each other and the school. The school has small class size, small overall school size, multiple-year student-teacher assignments, and, in higher grades, relatively few periodto-period shifts between teachers-all measures to encourage familiarity among students and teachers. The emphasis on student ideas and student presentations and projects as well as lengthy open-ended teacher-parent conferencing, are all designed to make each student feel as if she belongs, as if to a family.

\subsection{A Resource-Use Model of School Reform}

We interpret the creation of a school community as a choice about the allocation of resources within a school. The model shows when resources devoted to such a reform program will enhance educational attainment. Suppose a school has resources $r=1$ which it can divide into two uses, those directly devoted to the teaching of skills, in proportion $\alpha$, with the remainder, $1-\alpha$, devoted to creating community and reducing $t$, the social differences between the students and the school. ${ }^{69}$ Skills increase directly in $\alpha: k_{i}=\alpha s e_{i}\left(1-d_{i}\right)$, at the expense of social difference: we have $t(\alpha)$, which is also increasing in $\alpha$.

The school's objective function (for $p=0$ ) is now in the two-s and one-s case respectively:

$$
\begin{aligned}
& K= \alpha s_{\mathrm{H}}\left[\frac{1}{2}+\frac{m-s_{\mathrm{H}}}{\sigma}\right] e(\mathrm{H}) \\
&+\alpha s_{\mathrm{M}}\left[\frac{s_{\mathrm{H}}-s_{\mathrm{M}}}{\sigma}+\frac{I}{\sigma \cdot t(\alpha)}\right] e(\mathrm{M}) 2-s \text { Case } \\
& K=\alpha \cdot s \cdot e(S) \cdot(8) \\
&\left(\frac{1}{2}-\frac{s-m-I / t(\alpha)}{\sigma}\right) \\
& 1-s \text { Case }
\end{aligned}
$$

In the two-s case, the school chooses $s_{\mathrm{H}}, s_{\mathrm{M}}$ and $\alpha$; in the one-s case it chooses $s$ and $\alpha$. Solving first for the optimal ideals $-s^{*}$ in the $1-s$ case and $s_{\mathrm{H}}^{*}, s_{\mathrm{M}}^{*}$ in the two-s case-we see that optimal ideals are increasing in $(1-$ $\alpha$ ), the fraction of resources devoted to reducing social differences. As students identify more with the school, the school can promote an ideal that is more amenable to marketable skills. With an internal solution, $\alpha$ satisfies the following condition, which show the costs and benefits of such an investment:

$$
\begin{array}{r}
\frac{d K(\alpha)}{d \alpha}=\frac{K}{\alpha}-\alpha \cdot t^{\prime}(\alpha) \frac{I}{\sigma \cdot t(\alpha)}\left[s_{\mathrm{M}}^{*} e(\mathrm{M})\right] \\
=0 \quad 2-s \text { Case }
\end{array}
$$

69 It is possible that resources devoted to reducing $t$ are also directly complementary to skill acquisition-as many would argue that CPESS' special curriculum enhances learning.

$$
\begin{array}{r}
\frac{d K(\alpha)}{d \alpha}=\frac{K}{\alpha}-\alpha \cdot t^{\prime}(\alpha) \frac{I}{\sigma \cdot t(\alpha)}\left[s^{*} e(S)\right] \\
=0 \quad 1-s \text { Case }
\end{array}
$$


where $s^{*}$ and $s_{\mathrm{M}}^{*}$ are the optimal choices for a given $\alpha$. In both cases, investments in reducing $t$ result in a direct loss in skills due to diversion of resources, reflected in the first term $K / \alpha$. The benefit is an increase in the number of students who identify with the school. The second terms show the change in skills of these students.

There is an interior solution for $\alpha$ when $t(1)$ is sufficiently high ${ }^{70}$ When students initially think of themselves as quite different from the school, a small investment to reduce $t$ can have a large impact on skills. In this case, it is optimal to spend resources to change this social parameter. Furthermore, with sufficient investment in $t$, it is optimal for the school to promote a single ideal.

The model suggests that there is much greater similarity between the "liberal" and "conservative" reform agendas than is apparent in the often shrill debate. Both emphasize special curricula that create school communities. That is, both invest to reduce $t$ in order to raise the ideal $s$. Both are then stark contrasts to the Shopping Mall High which makes no attempt to change social parameters. We have already seen the distinct pedagogy and student ideal in CPESS. We see similar elements in Core Knowledge Charter Schools, a prime example of conservative reform. In these schools, students should learn what Hirsch (1996) identifies as "Core Knowledge." The central idea of the school-its $s$ in the language of the modelis the role of this curriculum in "promot[ing] a community of learners-for adults and children." 71 The aim of the curriculum and other aspects of the reform is to trump the effect of students' backgrounds on school participation. The rules of a school in Parker, Colorado illustrate. Students must wear uniforms and obey a dress code so strict it

\footnotetext{
${ }^{70}$ At $\alpha=0$, the condition is always positive, hence we must have $\alpha>0$. At $\alpha=1$, the condition is negative for $t^{\prime}(\alpha)$ sufficiently large (recall that $t^{\prime}(\alpha)$ is positive).

${ }^{71}$ See: http://www.coreknowledge.org/CKproto2 /about/index.htm\#BEN.
}

details socks, which "must be worn in a coordinated color with the school uniform and worn in a matching pair of the same color." Furthermore, students and parents must sign an agreement to abide by the school's code of discipline. ${ }^{72}$ These rules and codes of discipline, as we shall discuss next, delineate the boundaries of a school community and play important roles in reform programs.

\subsection{Discipline in Schools}

Establishing and enforcing a school's code of discipline involves a substantial use of resources and defines the school community. In the noneconomic accounts of schools and of educational reform, rules and discipline are a common theme. This emphasis echoes Kai Erikson's (1966) observations that by obeying the rules one becomes a part of the community, by breaking them, one becomes an outcast.

The reforms by James Comer of two New Haven schools exemplify the use of resources to establish and enforce the disciplinary code. ${ }^{73}$ Comer describes the situation when he arrived at Baldwin Elementary School as "shocking." Desperate teachers were unable to establish order. Children milled around, yelling and screaming, calling the teacher and each other names. ${ }^{74}$ Five years later order reigned, as depicted on the cover of his book, School Power: a classroom with all students neatly dressed, smiling at their desks, eagerly raising their hands. ${ }^{75}$

\footnotetext{
72 See: http://www.ckcs.net/.

${ }^{73}$ CPESS is another example of how a school's disciplinary procedures delineates the community. Students sent to the Director's office for misconduct are led through the Five Habits of Mind to sort out the problem (Meier (1.988, p. 50)). Such a method would be ineffectual if the students did not already identify with the school and its particular precepts.

${ }_{75}^{74}$ Comer (1980, p. 76).

${ }^{75}$ The children also achieved higher levels of academic achievement. Prior to the reforms, the school had performance ratings in math and reading at the bottom of New Haven's public schools.
} 
How did Comer achieve this transformation? Comer says that the success of his program comes from students' internalization of school values. This process involved use of resources. Teachers were trained how to respond to children who acted up. A central facility was established where children could take hold of their feelings, relax and play, before being returned to the classroom, ready to obey. Comer demonstrates the nature of the disciplinary process with the case of an angry fifth grader who had attacked a smaller child with his belt. Rather than simply punishing the student who misbehaved, the teacher, who had been trained to look for causes for misbehavior, wormed out of the boy that he was upset because his father had been denied a pass from jail for Christmas. She helped him write a letter to his father, but, at the same time, she also made him understand he could not take out his feelings on other children. ${ }^{76}$ That is, children were taught not only how to read, but also how to obey the rules.

Just as sociologists view schools' rules and disciplinary procedures as a window on schools' ideals, they also view lack of rules and lack of discipline as indicative of the failure of a school to promote academic and other values. Grant's description of the newly tolerant Hamilton High of the 1970s illustrates. The old consensus on appropriate behavior and rules had broken down with nothing to replace it. The principal explained:

We assumed through the fifties and the sixties that we had a set of rules that applied to everyone when in fact they didn't. The black community was basically compliant with the expectation of the white community. Then things began to change. Then you get into a situation [where] you say what are the rules? When I started teaching at Hamilton the kids were sent home if they wore dungarees. I laugh [to think we ever had such a rule]. But [in 1970] there were no rules. ${ }^{77}$

\footnotetext{
${ }^{76}$ Comer (1980, p. 118).

77 Grant (1988, p. 40)
}

A teacher who caught a boy cheating was told that she needed a witness. ${ }^{78}$ When the same conscientious teacher gave a student an $\mathrm{F}$ for a ghosted paper, she was forced to hand over all her documents to the student's lawyer, who was seeking evidence of prejudicial treatment. ${ }^{79}$ A student group, which called itself the Protesters, opposed all infringements on students' rights, including the school prerogative of searching student lockers. ${ }^{80,81}$

\subsection{Public versus Private Schools}

The modeling above also describes a difference between private and public schools. Economists and noneconomists have both urged public support for private schooling. While economists focus on agency issues, John Chubb and Terry Moe (1988), for example, advance a different argument for privatization. They see a benefit in the freedom private school administrators have to set goals and mobilize resources to achieve

${ }^{78}$ Grant (1988, p. 53).

${ }^{79}$ Grant (1988, p. 53).

${ }^{80}$ Grant (1988, pp. 60-61).

81 Judicial interpretations of the law governing schools' authority over students reveals changes in attitudes regarding school authority that coincided in time with the changes in the disciplinary system at Hamilton High. In the opinions of the landmark cases, as in our model, public schools have only limited authority to affect students' identity (see Anne Dupre 1996). The Tinker v. Des Moines (1969) and Goss v. Lopez (1975) decisions demarcate the break from the traditional view of schools as agents of parents (under the doctrine of in loco parentis) with the authority to enforce codes of discipline and mold students' morals and values. These decisions established that students are "persons" under the Constitution and do not shed their rights "at the schoolyard gate." Dupre (1996, p. 54) Tinker v. Des Moines concerns three students who were suspended after refusing to remove armbands in protest of the Vietnam War. The Supreme Court ruled that the school could not punish the students, since "Students in school as well as out of school are 'persons' under our Constitution. They possess fundamental rights which the state must respect . . . In the absence of a specific showing of constitutionally valid reasons to regulate their speech, students are entitled to freedom of expression of their views." Goss v. Lopez gave an analogous interpretation of students' rights to due process. See Dupre (1996, p. 57 ff). 
them. In terms of the model, setting goals can be seen as establishing an ideal $s$; the mobilization of resources can be seen as the use of resources to establish a community that will accept these goals. Private schooling is thus seen as relaxing constraints on investments to establish identity.

Chubb and Moe (1988, tables 4 to 8) support their view with data from the Teachers and Administrators Survey supplement to High School and Beyond. Batteries of responses show that private school principals have less interference from school boards and other administrators over curriculum, instruction, and discipline. They face less constraints on school policy and procedures concerning personnel, and hiring and firing. They have more support from parents in setting their goals and set greater goal clarity for their schools. In addition, Chubb and Moe show that the private school principals are viewed more affirmatively by their teaching staff, which is just one sign of a school community.

Peshkin's (1985) account of a Christian school in Illinois provides an extreme example of a private school that reaches into all aspects of a student's life. Parents and children sign detailed contracts, where parents not only grant the school the right to enforce a firm Christian code of discipline, they promise to enforce the school's code at home. ${ }^{82}$ The model characterized reduction in $t$ as narrowing the gap between school and home: this unusual measure brings the home closer to the school ideal.

\subsection{Empirical Evidence}

What evidence do we have that the establishment of community affects educational attainment? Are Comer's schools and CPESS just anecdotes? We argue the contrary. These programs changed the outcomes for populations of students. In epidemiology, a population that shows particular resistance or predilection for a disease is a research

${ }^{82}$ See Peshkin (1985, p. 90) opportunity. Researchers ask what makes this population different than the rest of us. Similarly, such reform programs can provide valuable information concerning the inputs to education.

Bryk and his colleagues (1993) conduct such a study. Catholic schools are known for their higher educational outcomes. ${ }^{83}$ Bryk et al. (1993) describe in detail how Catholic schools establish such a school community where students accept the school's goals and ideals. These schools make their ideals clear in their statements of philosophy. For example, one school defined its ideal student, who "should be marked by a number of characteristics: . . . intellectually competent, . . . loving, . . . a person of faith, . . . [and] committed to doing justice." 84 Each of the desirable characteristics is described in detail. Bryk et al..describe the arrangements that foster students' acceptance of these ideals (in our model investments in $t$ ). All the teachers assume responsibility for shaping student character and are supposed to be involved in many aspects of students' lives. ${ }^{85}$ Lack of specialization makes this feasible, as the English teacher of the morning is likely to be the counselor at lunch time and possibly the soccer coach of the afternoon. ${ }^{86}$

${ }^{83}$ Coleman, Hoffer, and Kilgore (1982) show that Catholic school students have higher test scores with lower standard deviations than public school students. See table $6-1, p .127$. The question remains to what extent these differences can be attributed to selection bias or school quality. Joseph Altonji, Todd Elder and Christopher Taber (2000), who also review the extensive literature on this subject, correct for selection bias by using the bias in the observables to correct for the bias in unobservables. They concentrate their analysis on a sample of students who were in Catholic schools in eighth grade, some of whom continued to Catholic high schools, and some of whom switched to public schools. They find that those who continued in the Catholic schools had considerably greater chance of graduating and attending college.

${ }^{84}$ See Bryk et al. (1993, p. 146).

${ }^{85}$ Bryk et al. (1993, p. 141): "Teachers convey an intrusive interest in students' lives that extends beyond the classroom door into virtually every facet of school life. In some cases it extends even to students' homes and families."

${ }^{86}$ Bryk et al. (1993, p. 141). 
Wide participation in school activities, including a greater fraction of students on athletic teams and shared religious activities, foster the school community. This community blurs distinctions between school and home: in the terms of our model, it reduces the social differences $t$.

These differences in community between the public schools and the Catholic schools are supported by statistical evidence. From High School and Beyond and the associated Administrator and Teacher Survey, Bryk et al. (p. 284) construct an aggregate index of school community from 23 sub-components, including such items as the likelihood that a teacher will know a given student, an index of students' perceptions of teacher interest, and an index of agreement on goals between teachers and administrators. The value of the aggregate index of community for Catholic schools is 2.35 standard deviations from the public school mean, as, in fact, the Catholic schools were more communal than the public schools for each and every one of the subcomponents. ${ }^{87}$

\section{Black-White Differences in School Attitudes and Achievement}

Our emphasis on social categories and identity captures arguments by leading scholars of black education such as James Banks, Comer, Delpit, Ferguson, Fordham,

\footnotetext{
${ }^{87}$ The subcomponent indices measure: teacher agreement on student goals, reported teacher consensus on beliefs and values, teacher beliefs that students can learn, teacher and administration agreement that students can learn, teacher and administration agreement on standards of discipline, student consensus about teacher role, track and course-taking commonality of students, teacher knowledge of students (in class), percent students involved in extracurricular activities, percent students in leadership roles, percent teachers who obtain help from colleagues, teacher cooperation with colleagues, teacher time planning with other teachers, staff commitment to evaluation, participation in faculty social events, teacher time in extended roles, percent of teachers involved in extracurricular activities, teacher knowledge of students (beyond class), teacher contact with students outside of class, and student perception of student interest.
}

John Ogbu, and Claude Steele. ${ }^{88}$ Clashes between black students and their school, as in Hamilton High, appear frequently in studies of black-white differences in educational attainment. Anthropological studies show how school routines and curricula can convey to black students that there is something "wrong" with them and their background. Delpit's classroom accounts show, for example, how teachers' presumption of superiority of standard English can (unknowingly) insult speakers of black dialect. In a reading lesson, a girl renders the text: "Yesterday I washed my brother's clothes," as "Yesterday I wash my bruvver close." The teacher corrects her. But the student has done something far more sophisticated than read: she has translated the passage into her own dialect. Instead of being praised, the girl is told that she has made a mistake. ${ }^{89}$ In microcosm, this incident captures some of the tension between students and schools with socially different ideals. This tension, Ogbu (1997) argues, leads to an "oppositional culture" on the part of black students. ${ }^{90}$

\subsection{Empirical Interpretation and Need for Future Work}

The empirical studies of black/white differences in education reveal a paradox, which might be resolved by the modeling in this paper. Tests of the theory of oppositional culture

${ }^{88}$ See for example: Banks and Dresden Grambs (1971), Comer (1980), Delpit (1995), Ferguson (1998a,b,c, 2001), Fordham (1996), Ogbu (1971), and Steele and Aronson (1998).

89 Delpit (1995, pp. 58-59). Delpit believes teaching standard English is especially important in poor Black neighborhoods. She suggests, for example, that English be taught as drama. Delpit $(1995$, p. 51$)$ also relates the following interchange between a teacher and a fouryear-old Black boy:

Teacher: Good morning, Tony, how are you?

Tony: I be's fine.

Teacher: Tony, I said, How are you?

Tony: (with raised voice) I be's fine.

Teacher: No, Tony, I said how are you?

Tony: (angrily) I done told you I be's fine and I ain't telling you no more.

${ }^{90}$ See also Fordham (1996). 
suppose that if black students are angered by school culture, they should have less favorable attitudes toward school than white students. The existing evidence suggests the contrary. Philip Cook and Jens Ludwig (1997) show that, compared to non-Hispanic whites, blacks have about the same expectations for educational attainment (high school, college, etc.) and about the same school attendance and levels of effort. ${ }^{91}$ Table 3 , with slightly different tabulations from High School and Beyond, shows blacks have better school attitudes than whites. On average compared to whites, blacks are less likely to "dread English class," less likely to "dread math class," more likely to perceive "school spirit as excellent," more likely to report a "positive attitude toward self" and much more likely to "like working hard in school." These findings seem paradoxical in view of the large and persistent gap between black and white test scores (Christopher Jencks and Meredith Phillips (1998)).

The possibility that schools adjust their curriculum and ideal to their student body yields a possible explanation why blacks appear to have better attitudes toward school than whites, but they have lower test scores. In the model of section 3 schools adjusted $s$ so that more students will identify with the school. In this case, it is likely that schools with a majority white (black) student population emphasize an ideal that conforms to their white (black) students. As a consequence, it is likely that black students, for example, are much more likely to "dread" English class and math class in white schools than in black schools, with the reverse for white students. Table 4 shows that when we divide the High School and Beyond sample accordingly, blacks in almost totally white schools are, indeed, significantly more likely to dread English and math than their counterparts in all-black schools. Symmetrically, white students in almost totally black schools are more likely to dread English; similarly, they also have a positive (although statisti-

\footnotetext{
${ }^{91}$ See also Roslyn Mickelson (1990).
}

cally insignificant) coefficient on the likelihood of dreading math relative to their peers at all-white schools. ${ }^{92}$

Using data collected by Bishop at Shaker Heights High School, Ferguson (2001) has also examined the relation between the black/white grade gap and racial differences in attitude toward school. Like Cook and Ludwig, and like ourselves, Ferguson finds little difference between black and white attitudinal scores. Thus, while within race differences in attitudes are well-correlated with GPA at Shaker Heights, differences between races explain little of the gap. ${ }^{93}$ This finding suggests that subjects' interpretation of the attitudinal questions differs by race. Ferguson's ethnographic findings of differences between black and white high-school students-some from schools other than Shaker Heights-indeed suggest that blacks and whites segregate themselves into different groups. He emphasizes that black students do not want to appear disloyal to their race. ${ }^{94}$ The modeling in this paper suggests that with such differences there should be a presumption that prescriptions, and therefore ideal levels of effort, will differ by group. We thus might expect that blacks and whites $^{95}$ will give similar responses to questions that subjects either consciously or unconsciously interpret as concerning the desirability of effort relative to the ideal of their respective group. With such interpretation, similarity of response does not imply similarity of ideal effort by group. Consider, for example, the meaning of student scalings of the following three statements: "It's not cool to be competitive about grades." "It's not cool to frequently volunteer answers or comments in class." "It's annoying when students

\footnotetext{
92 There could, of course, be other theories, such as selection bias that could explain these facts.

${ }^{93}$ See Ferguson (2001, p. 348).

94 See Ferguson (2001, pp. 377-78).

95 We would expect similar lack of difference between honors students and middle students at Shopping Mall High, except insofar as these two groups mix.
} 
TABLE 3

ATtITUdES OF STUdENTS BLACK/WHITE: OddS RATIO FROM LOGIT REgRESSIONS

Independent

Variable

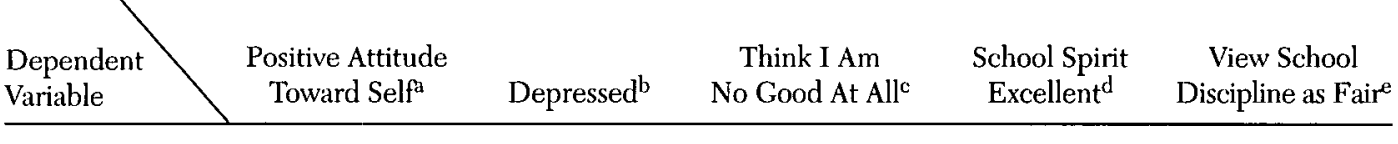

Male

\begin{tabular}{lccccc}
\hline Black & $2.27^{* *}$ & $1.5 \mathrm{l}^{* *}$ & 1.12 & $1.13^{* *}$ & 1.03 \\
& $(.09)$ & $(.15)$ & $(.09)$ & $(.05)$ & $(.07)$ \\
White & $.44^{* *}$ & $.66^{* *}$ & .89 & $.88^{* *}$ & .97 \\
& $(.02)$ & $(.07)$ & $(.07)$ & $(.04)$ & $(.07)$ \\
\hline
\end{tabular}

Female

\begin{tabular}{lccccc}
\hline Black & $3.65^{* *}$ & $1.52^{* *}$ & $.84^{*}$ & $1.15^{* *}$ & $1.28^{* *}$ \\
& $(.13)$ & $(.11)$ & $(.06)$ & $(.04)$ & $(.09)$ \\
White & $.27^{* *}$ & $.66^{* *}$ & $1.19^{*}$ & $.87^{* *}$ & $.78^{* *}$ \\
& $(.01)$ & $(.05)$ & $(.08)$ & $(.03)$ & $(.05)$ \\
\hline \hline
\end{tabular}

Source: High School and Beyond. "Positive attitude toward self: agrees strongly with statement "I take a positive attitude of myself"; bepressed: Respondents (sophomores only) felt depressed or unhappy a lot in past few weeks; "Think I am no good at all: Strong agreement with statement "At times I think I am no good at all";

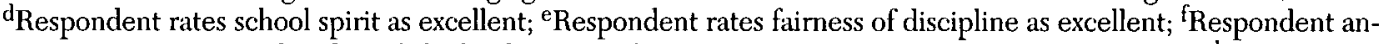
swers true to: Do you dread English class? gRespondent answers true to: Do you dread math class?; ${ }^{\mathrm{h}} \mathrm{ACT}$ or SAT:

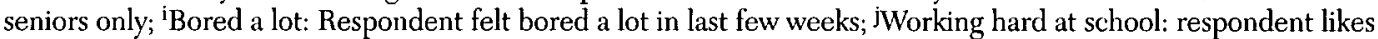

try to get teachers off track in class." 96 The behavior that students would define as "being competitive," "volunteering answers," or "getting teachers off track" is likely to differ by group. For example, while nerds and burnouts both disapprove of "being competitive about grades," the objective behavior envisaged by the two groups will be very different. Ferguson's accompaniment of ethnographic observation with his statistical analysis puts such responses in context. It suggests the need for further work that bases attitudinal questions on ethnographic observation. Those questions should solicit students' attitudes toward objectively defined behaviors, with no ambiguity that all stu-

\footnotetext{
${ }^{96}$ See Ferguson (2001, pp. 355-57) for these questions and others.
}

dents, regardless of their social group, will have the same objective interpretation of the questions. Such study, in our opinion, is the next natural step in resolution of the CookLudwig paradox.

\section{Further Implications for Future Empirical Work}

Here we sketch some further implications of the model for empirical work. Thus far, the empirical work that we have discussed has, mostly, used non-experimental dataas, for example, in the studies of Cook and Ludwig and of Ferguson. But we have mentioned both controlled and natural experiments. For example, the Comer schools were a controlled experiment, Hamilton 
TABLE 3 (cont.)

\begin{tabular}{cccccc}
$\begin{array}{c}\text { Dread English } \\
\text { Class }^{f}\end{array}$ & $\begin{array}{c}\text { Dread Math } \\
\text { Classg }\end{array}$ & $\begin{array}{c}\text { Taken ACT } \\
\text { or SAT }\end{array}$ & $\begin{array}{c}\text { Bored a } \\
\text { Lot }^{\mathrm{h}}\end{array}$ & $\begin{array}{c}\text { Like Working } \\
\text { Hard at Schoolj }\end{array}$ & $\begin{array}{c}\text { Disappointed if Do } \\
\text { Not Go to College }\end{array}$ \\
\hline $.55^{* *}$ & $.86^{*}$ & $.90^{*}$ & 1.14 & $2.23^{* *}$ & $(.09)$ \\
$(.04)$ & $(.05)$ & $(.04)$ & $(.08)$ & $.78^{* *}$ \\
$1.83^{* *}$ & $1.16^{* *}$ & $1.11^{* *}$ & .88 & $.45^{* *}$ & $(.08)$ \\
$(.12)$ & $(.07)$ & $(.05)$ & $(.06)$ & $(.02)$ & $.56^{* *}$ \\
\hline & & & Female & $(.02)$ \\
\hline $.67^{* *}$ & $.73^{* *}$ & $.86^{* *}$ & $1.39^{* *}$ & $2.04^{* *}$ & \\
$(.04)$ & $(.04)$ & $(.04)$ & $(.08)$ & $(.08)$ & $\left(.43^{* *}\right.$ \\
$1.49^{* *}$ & $1.37^{* *}$ & $1.16^{* *}$ & $.72^{* *}$ & $.49^{* *}$ & $.41^{* *}$ \\
$(.09)$ & $(.07)$ & $(.05)$ & $(.04)$ & $(.02)$ & $(.02)$ \\
\hline \hline
\end{tabular}

working hard at school; kDisappointed if do not go to college: agreement with statement "I will be disappointed if I do not go to college."

"Significant at $5 \%$ level; ${ }^{* *}$ significant at $1 \%$ level. Example: Odds Ratio $(\mathrm{OR})=$ Odds for Depressed (Black

Male)/Odds for Depressed (non-Black Male) $=1.51$, where Odds for depressed = probability of depressed/proba-

bility of not depressed; logit $(p)=a+b X ; O R=e^{b}$.

High a natural experiment. Indeed, Hamilton High gives a dramatic instance of a school's response to an exogenous (in this case, court-ordered) change in the diversity of its student body. For this reason it is a good test of our model. Hampel (1986) relates similar disturbances in other schools with forced integration in the same time period. The work of Grant and Hampel should be carried further. Whether changes in test scores relate to court-ordered busing can be examined statistically. The model predicts that, as in Hamilton High, the impulse response to court-ordered busing will be a reduction in test scores, followed by a less than complete recovery.

Another example where our theory suggests a broader scope of empirical work in the economics of education comes from
Krueger and Whitmore (1999). They examined the consequences of Tennessee's Star experiment, in which students in grades $\mathrm{K}$ to 3 were randomly assigned to small classes. For the duration of the experiment, black and free-lunch subjects had large and statistically significant gains in the Stanford Achievement Test. After returning to normal-sized classes, these gains disappeared. Despite this disappearance, eight years after they had left the experiment, blacks who had been in the small classes were twenty-five percent more likely to take college entrance exams (ACT or SAT) than those in control groups ${ }^{97}$ Our perspective suggests that such an astounding finding should be followed up,

${ }^{97} 40.2$ percent compared to 31.7 . Krueger and Whitmore (1999, p. 11). 
TABLE 4.

Coefficients from Logit Regressions for Dread English/Dread Math By Black/White AND RaCial COMPOSITION OF SCHOOL

\begin{tabular}{|c|c|c|c|c|}
\hline & $\begin{array}{l}\text { Dread English }^{\mathrm{d}} \\
\quad \mathrm{N}=2995\end{array}$ & $\begin{array}{l}\text { Dread Mathe } \\
\qquad N=3011\end{array}$ & $\begin{array}{l}\text { Dread English } \\
\quad \mathrm{N}=19727\end{array}$ & $\begin{array}{c}\text { Dread Math } \\
\mathrm{N}=19678\end{array}$ \\
\hline & \multicolumn{2}{|c|}{ Black $^{f}$} & \multicolumn{2}{|c|}{ White $^{f}$} \\
\hline All White in Schoola & $\begin{array}{l}.76^{*} \\
(.34)\end{array}$ & $\begin{array}{l}.72^{*} \\
(.32)\end{array}$ & - & - \\
\hline Few Black in School & $\begin{array}{l}.24 \\
(.15)\end{array}$ & $\begin{array}{l}-.11 \\
(.14)\end{array}$ & $\begin{array}{l}-.10^{* *} \\
(.04)\end{array}$ & $\begin{array}{r}-.08^{*} \\
(.04)\end{array}$ \\
\hline Half Black in School & $\begin{array}{l}.18 \\
(.14)\end{array}$ & $\begin{array}{c}.06 \\
(.13)\end{array}$ & $\begin{array}{l}-.05 \\
(.05)\end{array}$ & $\begin{array}{l}.01 \\
(.05)\end{array}$ \\
\hline Mostly Black in School & $\begin{array}{c}-.12 \\
(.15)\end{array}$ & $\begin{array}{l}.02 \\
(.13)\end{array}$ & $\begin{array}{l}.07 \\
(.09)\end{array}$ & $\begin{array}{l}.10 \\
(.09)\end{array}$ \\
\hline All Black in School ${ }^{b}$ & - & - & $\begin{array}{l}1.15^{* *} \\
(.31)\end{array}$ & $\begin{array}{c}.31 \\
(.31)\end{array}$ \\
\hline SES & $\begin{array}{c}-.48 \\
(.62)\end{array}$ & $\begin{array}{c}-.50 \\
(.58)\end{array}$ & $\begin{array}{c}-3.52^{* *} \\
(.23)\end{array}$ & $\begin{array}{c}-1.52^{* *} \\
(.22)\end{array}$ \\
\hline Constant & $\begin{array}{c}-1.47^{* *} \\
(.12)\end{array}$ & $\begin{array}{c}-1.09^{* *} \\
(.11)\end{array}$ & $\begin{array}{l}-.77^{* *} \\
(.03)\end{array}$ & $\begin{array}{c}-.77^{* *} \\
(.03)\end{array}$ \\
\hline
\end{tabular}

Source: High School and Beyond. "No black students in respondents' ninth grade; ball black students in respondents' ninth grade; 'Duncan index of parents' socioeconomic status from parents' survey (measure of SES is the Duncan index times 10,000); 'no black students in respondents' ninth grade; ${ }^{\mathrm{d}}$ Affirmative response: Do you dread English class?; eAffirmative response: Do you dread math class?; ' Inclusive of Hispanics by race.

Standard errors are reported in parentheses. ${ }^{* *}$ Significant at $1 \%$ significance level; ${ }^{*}$ significant at $5 \%$ significance level. Regressions for Black: All black in school was omitted dummy. Regressions for White: All white in school was omitted dummy. Regression: $\operatorname{logit}(\mathrm{p})=\mathrm{a}+\mathrm{bX}$.

since the economics of education should not just tabulate the effects of experiments. Research should also ascertain how and why the experimental subjects were subsequently different.

Our theory suggests a possible testable explanation: the familiar environments afforded by small class sizes trumped these students' tendency to view school as a place for others, rather than for them. Otherwise, it is hard to explain why almost a decade later they were more likely to see themselves as suitable candidates for colleges requiring entrance exams. Empirically we would expect to see this difference in attitude toward school reflected in greater participation in school activities.
Using currently available data, it is possible to use measures of school participation to test the hypothesis that successful past experiments are associated with a greater sense of belonging to the school community. High-school yearbooks provide an indicator of school participation. Typically the captions of photographs of sports teams and clubs list the names of participants. Also, appearance for the graduation picture in the yearbook itself is another (minimal) form of school participation. With the Star experiment, even now, it would be possible to use such data to test for differences in high-school participation by those in the experimental and the control groups. It would also be possible to see whether such 
difference in participation was correlated with taking the ACT.

Such follow-up is also possible for the Comer experiment. Test scores at the Comer schools rose markedly in the first five years of the experiment. The yearbook records of these students in high school should show whether the effects of the experiment continued, in the form of greater participation in school life. This evidence should be particularly powerful since the high-school record of increased participation should mirror the increasing success of the experiment in its first five years. ${ }^{98}$ Such studies would expand the boundaries of empirical work in the economics of education, as their goal is not only to measure the consequences of changes in resources, but also, more deeply, to resolve, the reasons for these consequences.

While a considerable econometric literature has reexamined the assertions of superior performance of Catholic and other private schools by Coleman and others, there is still the need to reexamine the more ambitious assertions in this literature regarding the reasons for such superiority. Bryk et al. and Chubb and Moe have established good correlations, respectively, between indices of community and of school independence and student performance. But causality runs in two directions-especially since affluent school districts and schools with high proportions of middle class students are likely to find it easier both to establish community and to give school administrators large scope

${ }^{98}$ Establishing the role of school participation from such experiments would test the hunches of Hollingshead in Elmtown's Youth, where he found a strong relation between participation in school activities and social class. (See Hollingshead 1975, pp. 143-50). Participation was especially low by the students of the lowest class, who lived near the canal and had a high rate of drop out. A girl of one of the lower classes explains to Hollingshead the reasons why she does not go to football games: 'Well, why go? We're made to feel out of place and that is the way it is." (1975, p. 150). This paper has explored the consequences of such feelings much more generally. for discretion. ${ }^{99}$ Researchers should reexamine the extent to which school community .and administrator independence causally affect student performance.

\section{Conclusion}

This review considers a sociological perspective on students and schools and integrates this perspective into an economic model. This view focuses on variablesidentity, social categories, and school ideals - that have been beyond the purview of the economic theory of education. The framework we suggest captures phenomena that could not be explained by standard economic modeling. It easily explains the sequence of events at Hamilton High, the implications of school discipline and changes in the legal status of students, the success of notable school reform experiments such as CPESS and the Comer schools, the tradeoffs in the Shopping Mall High, and arguments of non-economists in favor of school vouchers and charter schools.

The last model incorporates all the previous modeling in the paper to consider the use of school resources to change student identities. The model combines the fundamental concern of economists - the allocation of resources-with a basic concern of education scholars-the dependence of students'

${ }^{99}$ For example, Chubb and Moe (1990) define low and high performance schools as those respectively in the bottom and top quartiles of sophomore-to-senior improvement on a test administered to the High School and Beyond panel. In the high performance schools principals had more motivation to control the schools. In schools in the top quartile of improvement, 61.9 percent had higher than average motivation to control, as measured by their index, in contrast to only 18.9 percent in the bottom quartile. (See Chubb and Moe 1990, p. 85). These tabulations and others show a difference in performance between successful and unsuccessful schools in the exercise of leadership of principals. While Chubb and Moe are well aware that causality runs in both directions, their attempts to establish causality of school independence are not convincing. Quite possibly with the type of panel data available to them from High School and Beyond such causality cannot be identified. 
achievement on the gap between their own self-images and the person the school intends them to be. In our reading of the noneconomic literature, we were struck by the absence of comment on the role of resources in schooling. Consider three examples. In Powell et al.'s account of Shopping Mall High, a defining moment occurs when a teacher fails to reprimand a student for complaining about an assignment. The authors consider this response as a failure to set standards and change the student's own expectations of what she could achieve: in the language of our models she failed to promote an academic ideal. But straightforward economics offers another interpretation: the teacher is incompetent or lazy. If incompetent, the school lacks resources; if lazy, she lacks the right incentives. Descriptions of CPESS and the Comer Schools similarly fail to consider the exceptional resources available to these schools, not in terms of budget, perhaps, but in terms of exceptional teaching and administration.

The perspective offered by our models is thus consistent with the view of Hanushek (1986) and Ferguson (1998b) that resources, especially in the form of high teacher quality, are critical ingredients for school reform. But the sociological perspective says more. It says that the resource use is likely to be ineffective when students' backgrounds are antithetical to the academic values that schools should promote and the schools are constrained against investing in identity. ${ }^{100,101}$ This perspective, as we have seen, offers a possible explanation why the experimental seniors in the Star experiment had such a high rate of taking the ACT or SAT exam. Sizer's (1984) claims about teachers and student self-image can similarly be interpreted as a reason for a relation

\footnotetext{
${ }^{100}$ On average teachers with greater academic skills will be better motivated themselves, and will thus more naturally motivate their students.

101 Jeffrey Mirel (1999) has documented, in the case of Detroit, the decline in the resources available for an ever more difficult task in maintaining a pro-education, pro-academic morale for the period 1930-80.
}

between resources and academic achievement. Sizer sees the typical U.S. high school as unable to affect student character since the typical teacher meets with 120 students every day, ${ }^{102}$ making close student-teacher relations all but impossible.

This synthesis of the sociology and the economics shows why new research in economics should delve into the black box of the school. Our task is not only to determine whether an experiment or resources increase educational achievement. Our task is also to explain why. The sociological approach outlines possible answers, and directions for new research within the economics of education.

In closing we should mention two important omissions from this review and from its theoretical framework. We have focused on the identity and behavior of students, but the motivations of teachers and administrators are also keys to the success of different schools. As we saw briefly in the accounts of CPESS, the teachers and principal identified with the goals of the school. Indeed they created them. The committed Catholic School teachers and administrators, described by Bryk et al., contrasts with the disengaged public school teacher, described by Sizer. ${ }^{103}$ Thus the extent to which teachers identify with their school's mission may be as important as differences in student motivation in explaining the gap in performance between the two systems.

Second, reflecting our own bias as economists, our models assume that schools maximize students' marketable skills. But skills are only one of the goals of some schools and of the parents who choose them. Religious schools, for example, often eschew economic goals in favor of religious goals. In some cases, they view their primary mission as the separation of the saved from the damned, as

${ }^{102}$ Sizer (1984, p. 97).

${ }^{103}$ See Bryk et al. (1993) and Sizer (1984). Parents' and administrators' identities also play a role in the operation of the school. Comer (1980) and Ogbu (1997) emphasize the role of parents in their children's identification with or against school. 
suggested by the fears of the principal in Peshkin's ethnography: "The devil's crowd [the unconverted] is after our kids." 104 A similar desire for separation lay behind the voucher-supported private academies established (unconstitutionally) in the wake of Brown v. Board of Education of Topeka, Kansas (Jeffrey Henig 1993). ${ }^{105}$ The goals and curricula of public schools are the product of elected school boards; the nature of these schools, their ideals, may then derive from the political economy of a community. ${ }^{106}$ If schools' goals include promoting certain ideologies, school choice may be neither skill-increasing nor ideologically neutral. ${ }^{107}$

${ }^{104}$ See Peshkin (1985, p. 289).

105 Some African-American charter schools also have separatist teachings (Lynell George 1992).

${ }^{106}$ See Foley (1990) for school board battles and the history of Anglo and Mexican-American relations in the West Texas town he studied. Many current education policies, including vouchers, sex education in public schools, bilingual instruction, etc. are being determined at the ballot box.

107 The political economy model of Kremer and Sarychev (1998) deals nicely with the issue of ideological choice in public and private schools. In their model parents choose among schools that promote different ideologies. After their education, people with different ideologies have less gains from trade. Parents want their children to be like them ideologically, but they also want their children to be able to communicate with others for economic gain. A school's ideal in our descriptive model is similar to school ideology in Kremer and Sarychev, and our model produces a related trade-off. Schools interested in students' skills have a reason to choose the ideology of the dominant culture because that is the idiom of commerce, but they have reason to mirror their students' preferences. Our description of school reform which empowers investments in identity and relaxes the public school constraint in these investments yields different analysis of the potential benefits and costs of school privatization. Consider the seeming paradox in the Netherlands of ideological homogeneity and private schooling, which Kremer and Sarychev explain as the lucky draw from multiple equilibria. In our descriptive model, private schooling will result in more homogeneity than public schooling if parents care sufficiently about children's skills. Private schools will devote resources, $\alpha$, to reduce any conflict between students' identity and the dominant culture, and then choose an ideal, $s$, that conforms to the dominant culture as well. In contrast, constrained public schools must mimic the heterogeneity already existing in society. Friedman (1955) discusses the issue of school ideological concerns.

\section{REFERENCES}

Akerlof, George A. and Rachel E. Kranton. 2000. "Economics and Identity," Quart. J. Econ. 105:3, pp. 715-53.

Alesina, Alberto; Reza Bagir and William Easterly. 1999. "Public Goods and Ethnic Divisions," Quart. J. Econ. 114:4, pp. 1243-84.

Altonji, Joseph G.; Todd R. Elder and Christopher R. Taber. 2000. "Selection on Observed and Unobserved Variables: Assessing the Effectiveness of Catholic Schools," NBER work. paper 7831.

Banks, James A. and Dresden Grambs, eds. 1972. Black Self-Concept: Implications for Education and Social Science. NY: McGraw-Hill.

Becker, Gary. 1964. Human Capital: A Theoretical and Empirical Analysis with Special Reference to Education. NY: Columbia U. Press.

Benabou, Roland. 1993. "Workings of a City: Location, Education, and Production," Quart. J. Econ. 108:3, pp. 619-52.

Betts, Julian R. 1995. “Does School Quality Matter? Evidence from the National Longitudinal Survey of Youth," Rev. Econ. Statist. 77:2, pp. 231-50.

Bishop, John H. 1998. "Nerd Harassment, Incentives, School Priority and Learning," mimeo, Cornell U.

Bloom, Allan. 1987. The Closing of the American Mind. NY: Simon and Schuster.

Bonny, Andrea; Maria T. Britto, Brenda K. Klostermann, Richard W. Hornung and Gail S. Slap. 2000. "Social Disconnectedness: Identifying Adolescents at Risk," Pediatrics 106:5, pp. 1017-21.

Bowles, Samuel and Herbert Gintis. 1976. Schooling in Capitalist America: Educational Reform and the Contradictions of Economic Life. NY: Basic Books.

Bowles, Samuel; Herbert Gintis and Melissa Osborne. 2001. "The Determinants of Earnings: A Behavioral Approach," J. Econ. Lit. 39:4, pp. 1137-76.

Brown, Roger. 1986. Social Psychology: The Second Eclition. NY: Free Press.

Bryk, Anthony S.; Valerie E. Lee and Peter B. Holland. 1993. Catholic Schools and the Common Good. Cambridge, MA: Harvard U. Press.

Card, David and Alan B. Krueger. 1992a. "Does School Quality Matter? Returns to Education and the Characteristics of Public Schools in the United States,"J. Polit. Econ. 100:1, pp. 1-40.

_ 1992b. "School Quality and Black-White Relative Earnings: A Direct Assessment," Quart. J. Econ. 107:1, pp. 151-200.

Chubb, John E. and Terry Moe. 1988. "Politics, Markets, and the Organization of Schools," Amer. Polit. Sci. Rev. 82:4, pp. 1065-87.

1990. Politics, Markets and America's Schools. Washington, DC: Brookings Institution Press.

Cohen, Jere. 1979. "High School Subcultures and the Adult World," Adolescence 14:55, pp. 491-502.

Coleman, James S. 1961. The Adolescent Society: The Social Life of the Teenager and Its Impact on Education. NY: The Free Press.

Coleman, James S.; Thomas Hoffer and Sally Kilgore. 1982. High School Achievement: Public, Catholic and Private Schools Compared. NY: Basic Books. 
Comer, James P. 1980. School Power: Implications of an Intervention Project. NY: The Free Press.

1988. Maggie's American Dream: The Life and Times of a Black Family. NY: New American Library.

Conant, James B. 1959. The American High School Today: A First Report to Interested Citizens. NY: McGraw-Hill.

Cook, Philip J. and Jens Ludwig. 1997. "Weighing the Burden of 'Acting White': Are There Race Differences in Attitudes Toward Education?" J. Polit. Anal. Manage. 16:2, pp. 256-78.

Delpit, Lisa. 1995. Other People's Children: Cultural Conflict in the Classroom. NY: The New Press.

Dupre, Anne Proffitt. 1996. "Should Students Have Constitutional Rights? Keeping Order in the Public Schools," George Washington Law Rev. 65:1, pp. 49-105.

Eckert, Penelope. 1989. Jocks and Burnouts: Social Categories and Identity in the High School. NY: Teachers College Press.

Epple, Dennis and Richard E. Romano. 1998. "Competition Between Private and Public Schools, Vouchers, and Peer Group Effects," Amer. Econ. Rev. 88:1, pp. 33-62.

Erikson, Kai. 1966. The Wayward Puritans: A Study in the Sociology of Deviance. NY: Wiley.

Evans, William N. and Robert M. Schwab. 1995. "Finishing High School and Starting College: Do Catholic Schools Make a Difference?" Quart. J. Econ. 110:4, pp. 941-74.

Evans, William N.; Wallace E. Oates and Robert M. Schwab. 1992. "Measuring Peer Group Effects: A Study of Teenage Behavior," J. Polit. Econ. 100:5, pp. 966-91.

Everhart, Richard. 1983. Reading, Writing, and Resistance: Adolescence and Labor in a Junior High School. London: Routledge \& Kegan Paul.

Ferguson, Ronald F. 1998a. "Teachers' Expectations and the Black-White Test Score Gap," in The BlackWhite Test Score Gap. Christopher Jencks and Meredith Phillips, eds. Washington, DC: Brookings Institution Press, pp. 273-317.

1998b. "Can Schools Narrow the Test Score Gap?" in. Jencks and Phillips, op. cit., pp. 318-74.

1998c. "Comment" on Philip J. Cook and Jens Ludwig, "Weighing the 'Burden of 'Acting White': Are There Race Differences in Attitudes Toward Education?" in Jencks and Phillips, op. cit., pp. 394-97.

2001. "A Diagnostic Analysis of Black-White GPA Disparities in Shaker Heights, Ohio," Brookings. Pap. Educ. Pol. 2001, pp. 347-414.

Fernandez, Raquel and Richard Rogerson. 1996. "Income Distribution, Communities, and the Quality of Public Education," Quart. J. Econ. 111:1, pp. 135-64.

Fliegel, Seymour. 1993. Miracle in East Harlem: The Fight for Choice in Public Education. NY: Random House.

Foley, Douglas E. 1990. Learning Capitalist Culture: Deep in the Heart of Texas. Philadelphia: U. Pennsylvania Press.
Fordham, Signithia. 1996. Blacked Out: Dilemmas of Race, Identity and Success at Capital High. Chicago: U. Chicago Press.

Friedman, Milton. 1955. "The Role of Government in Education," in Economics and the Public Interest. Robert A. Solo, ed. New Brunswick, NJ: Rutgers U. Press, pp. 123-44.

Friedman, Milton and Rose Friedman. 1980. Free to Choose: A Personal Statement. NY: Harcourt Brace.

Gaviria, Alejandro and Steven Raphael. 1997. "SchoolBased Peer Effects and Juvenile Behavior," U. Cal. San Diego discuss. paper 97-21.

George, Lynell. 1992. No Crystal Stair: African-Americans in the City of Angels. London: Verso.

Goldin, Claudia and Lawrence F. Katz. 1997. "Why the United States Led in Education: Lessons from Secondary School Expansion, 1910-1940," NBER work. paper 6144.

Grant, Gerald. 1988. The World We Created at Hamilton High. Cambridge, MA: Harvard U. Press.

Hampel, Robert L. 1986. The Last Little Citadel: American High Schools Since 1940. Boston: Houghton Mifflin.

Hanushek, Eric A. 1971. "Teacher Characteristics and Gains in Student Achievement," Amer. Econ. Rev. Pap. Proceed. 61:2, pp. 280-88.

1986. "The Economics of Schooling: Production and Efficiency of Public Schools," J. Econ. Lit. 24:3, pp. 1141-77.

Hanushek, Eric A.; Steven G. Rivkin and Lori L. Taylor. 1996. "Aggregation and Estimated Effects of School Resources," Rev. Econ. Statist. 78:4, pp. 611-27.

Harris, Judith R. 1998. The Nurture Assumption: Why Children Turn Out the Way They Do. NY: Simon and Schuster.

Henig, Jeffrey R. 1993. Rethinking School Choice: Limits of the Market Metaphor. Princeton: Princeton U. Press.

Hollingshead, August B. 1949. Elmtown's Youth: The Impact of Social Class on Adolescents. NY: John Wiley.

. 1975. Elmtown's Youth and Elmtown Revisited. NY: John Wiley.

Hoxby, Caroline M. 1996. "The Effects of Private School Vouchers on Schools and Students," in Holding Schools Accountable: PerformanceBased Reform in Education. H. Ladd, ed. Washington, DC: Brookings Institution Press, pp. $177-208$.

12000. "The Effects of Class Size on Student Achievement: New Evidence from Population Variation," Quart. J. Econ. 115:4, pp. 1239-85.

Jencks, Christopher and Meredith Phillips. 1998. The Black White Test Score Gap. Washington, DC: Brookings Institution Press.

Kremer, Michael and Andrei Sarychev. 1998. "Why Do Governments Operate Schools?" mimeo, M.I.T.

Krueger, Alan B. and Diane M. Whitmore. 1999. "The Effect of Attending a Small Class in the Early Grades on College-Test Taking and Middle School Test Results: Evidence from Project STAR," mimeo, Ind. Rel., Princeton U. 
Krug, Edward A. 1964. The Shaping of the American High School: 1880-1920. Madison, WI: U. Wisconsin Press.

1972. The Shaping of the American High School: 1920-1941. Madison, WI: U. Wisconsin Press.

Levine, David I. and Gary Painter. 2000. "Are Measured School Effects Just Sorting?" mimeo, U. Cal. Berkeley.

Manski, Charles F. 1992. "Educational Choice (Vouchers) and Social Mobility," Econ. Ed. Rev. 11:4, pp. 351-69.

Meier, Deborah. 1995. The Power of Their Ideas. Boston: Beacon Press.

Mickelson, Roslyn A. 1990. "The Attitude-Achievement Paradox Among Black Americans," Sociology Ed. 63:1, pp. 44-61.

Miguel, Edward. 1999. "Ethnic Diversity and School Funding in Kenya," mimeo, Harvard U.

Mirel, Jeffrey. 1999. The Rise and Fall of an Urban School System: Detroit, 1907-1981, 2nd ed. Ann Arbor: U. Michigan Press.

Ogbu, John U. 1974. The Next Generation: An Ethnography of Education in an Urban Neighborhood. NY: Academic Press.

_ 1997. "Beyond Language: Ebonics, Proper English and Identity in a Black American Speech Community," mimeo, U. Cal. Berkeley, Dept. Anthropology.

Powell, Arthur G.; Eleanor Farrar, and David K. Cohen. 1985. The Shopping Mall High School: Winners and Losers in the Educational Marketplace. Boston: Houghton Mifflin.

Peshkin, Allen. 1986. God's Choice: The Total World of a Fundamentalist Christian School. Chicago: U. Chicago Press.

Ravitch, Diane. 1983. The Troubled Crusade: American Education 1945-1980. NY: Basic Books.

Rumbaut, Rubén G. 2000. "Children of Immigrants and Their Achievement: The Role of Family, Acculturation, Social Class, Gender, Ethnicity, and School Contexts," mimeo, Michigan State U.

Sacerdote, Bruce. 2000. "Peer Effects with Random Assignment: Results for Dartmouth Roommates," NBER working paper 7469 .
Sadowski," Michael. 2001. "Closing the Gap One School at a Time," Harvard Education Letter, May/June. http://www.edletter.org/past/issues/2001$\mathrm{mj} / \mathrm{gap}$.shtml.

Schultz, Theodore W. 1960. "Capital Formation by Education," J. Polit. Econ. 68, pp. 571-83.

Sizer, Theodore R. 1984. Horace's Compromise: What Works for the American High School. Boston: Houghton Mifflin.

1996. Horace's Hope: What Works for the American High School. Boston: Houghton Mifflin.

Steele, Claude M. and Joshua Aronson. 1998. "Stereotype Threat and Test Performance of Academically Successful Americans," in Jencks and Phillips, op. cit., pp. 401-27.

Summers, Anita A. and Barbara L. Wolfe. 1977:2. "Do Schools Make A Difference?" Amer. Econ. Rev. Pap. Proceed. 67, pp. 639-52.

Tajfel, Henri and John Turner. 1979. "An Integrative Theory of Intergroup Conflict," in The Social Psychology of Intergroup Relations, William G. Austin and Stephen Worchel, eds. Monterey, CA: Wadsworth, pp. 33-47.

Tiebout, Charles M. 1956. "A Pure Theory of Local Expenditures," J. Polit. Econ. 64:5, pp. 416-24.

Tyack, David. 1974. The One Best System. Cambridge, MA: Harvard U. Press.

Valenzuela, Angela. 1999. Subtractive Schooling: U.S.Mexican Youth and the Politics of Caring. Albany: State U. New York Press.

Weiss, Lois. 1990. Working Class Without Work: High School Students in a De-industrializing Economy. NY: Routledge.

Wetherell, Margaret. 1996. "Group Conflict and the Social Psychology of Racism," in Identities, Groups and Social Issues. Margaret Wetherell, ed. Thousand Oaks, CA: Sage Pub., pp. 219-27.

Willis, Paul R. 1977. Leaming to Labour: How Working Class Kids Get Working Class Jobs. Westmead, Farnborough, Hants, England: Saxon House.

Wynne, Edward A. and Kevin Ryan. 1997. Reclaiming Our Schools: Teaching Character, Academics and Discipline. 2nd ed. Upper Saddle River, NJ: Prentice-Hall. 
Copyright of Journal of Economic Literature is the property of American Economic Association and its content may not be copied or emailed to multiple sites or posted to a listserv without the copyright holder's express written permission. However, users may print, download, or email articles for individual use. 